\title{
Non-Performing Property Loans and its Origination in the Real Estate Finance System: Case Study of Malaysia
}

\author{
Tham Kuen Wei ${ }^{1 *}$ and Rosli Said ${ }^{1}$ \\ ${ }^{1}$ Centre for Sustainable Urban Planning \& Real Estate, Faculty of Built Environment, Universiti Malaya, 50603 \\ Kuala Lumpur, Malaysia \\ *Email: thamkuenwei@hotmail.com
}

\begin{abstract}
A healthy real estate finance system is crucial for any economy to grow and thrive. However, in recent years, the sustainability and soundness of the Malaysian Real Estate Finance System had been in question as the number of non-performing property loans had been on the rise. This paper looks into how property NPLs originate within the real estate finance system in Malaysia and its current performance in Malaysia. A descriptive research design was conducted utilizing in-depth case studies of Malaysia to examine Malaysia's real estate finance system consisting of loan originators in the primary market and the special purpose vehicle involved at the secondary mortgage market where it was found that the Malaysian Real Estate Finance System is efficiently developed and on par with other developed countries with a robust primary mortgage market, effective secondary mortgage market and a vibrant capital market. Further analysis found that there are a total of 57 financial institutions that are property loan originators in Malaysia that consists of 26 Commercial Banks, 16 Islamic Banks, 2 International Islamic Banks, 11 Investment Banks, and 2 Special Financial Institutions. In terms of NPLs in Malaysia, property loans are the largest component of total NPLs in the country, and subsequent analysis found that the number of property NPLs in the country had been rising since 2015, after a long decade decline. This study warrants further research into the causes of property NPLs in the country so that the causes of property NPLs can be monitored as part of the country's strategic monetary policy to control and reduce the number of property NPLs in the country. Ultimately, this also helps to contribute towards a sound and robust real estate finance system in Malaysia.
\end{abstract}

Keywords: Non-Performing Property Loans, Real Estate Finance System, Primary Mortgage Market, Secondary Mortgage Market, Capital Market

\subsection{INTRODUCTION}

A healthy real estate finance system is crucial for any economy to grow and thrive (Valencia, 2018; Khan, 2011). In a developing nation like Malaysia, it is even more crucial when topics like affordable housing, development of infrastructure, and economic growth all require proper real estate financing to materialise. The real estate financing system serves this purpose, moving funds from surplus units to deficit units in the form of bridging and end financing to power and turn the wheels of the Malaysian economy (Cummings, 2006; Graaskamp, 1989). However, in recent years, the sustainability and soundness of the Malaysian Real Estate Finance System had been in question as the number of non-performing property loans had been on the rise (Bank Negara Malaysia, 1997-2018). The rising number of non-performing loans bring forth impending doom for the financial system, which had been found to cause systemic economic crises (Agnello, 2011). As financial institutions struggle 
e-issn: $2229-8568$

with non-performing loans (NPLs), they face credit illiquidity (Hou, 2007). A systemic phenomenon of credit illiquidity caused by macroeconomic factors will cause a group or all financial institutions within a country to collapse, leading to a systemic banking crisis (Valencia, 2018; Hou, 2007). A systemic banking crisis is a situation where a country's corporate and financial sectors experience a rising number of NPLs, with corporations and financial institutions face great difficulties repaying their debt obligations on time (Campbell, 2007; Beck, 2006).

In the last few decades, Malaysia had been affected and impacted by various systemic banking crises, including the 1997 Asian Financial Crisis and the infamy 2007 sub-prime mortgage crisis in the United States. In both these crises, there is a similarity on the systemic banking crises that happen during the 1997 Asian Financial Crisis, burdening NPLs in South Korea and China further exacerbated the financial crisis in the South East region (Koo \& Kiser, 2001). The increase of loan defaults in the United States, which are undetected alongside with lack of regulation and proper policies on lending practices brought the economy to its knees. Specifically, Adebola (2011) found that non-performing loans (NPLs) are one of the main causes of the 1997 economic downturn in Asia that damaged not only regional Asian countries but also the economies of many countries of the world. In these financial crises, as banks collapse, these systemic banking failures negatively affect the economy by harming the credit flow in the country which ultimately affects the efficiency and productivity of the economy (Rajaraman, 1999). Up to this day, non-performing loans remain the dominant risk for banking and financial institutions worldwide, including Malaysia (Khan, 2011).

\subsection{LITERATURE REVIEW}

\subsection{Real Estate System}

Real Estate system is the interaction at a broad relationship between the concepts of development, investment, and consumption in which the factor of production of land is utilised with public investments in services and infrastructure where it is used to justify both the purpose of development and investment costs (Graaskamp, 1989). Graaskamp (1989) found that the real estate development process involves three distinct groups of (i) users, (ii) developers, and (iii) infrastructure, investors. Yet, the main hurdle to any development is finance to fund it through. The user or firm will require finance to pay for the lease or purchase of a developed property, while the developer will require finance to develop such properties. The following shows a typical real estate system as described by Graaskamp (1989). 
e-issn: $2229-8568$

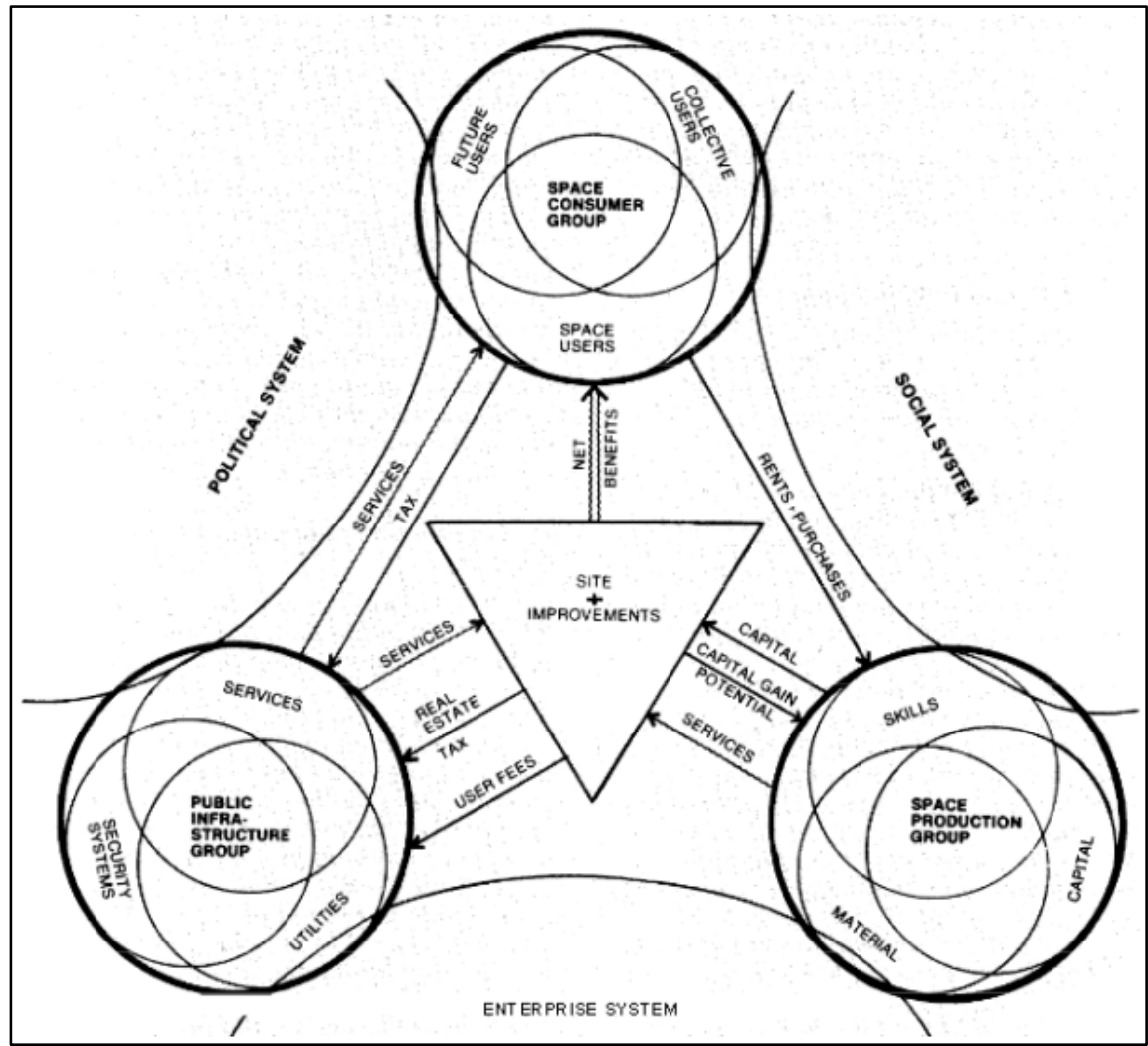

Figure 1: The Real Estate System, adopted from Graaskamp (1989) Source: Graaskamp, 1989

As shown in the diagram above, Space consumer groups consist of three types, namely future users, collective users, and space users. The collective space users are moralistic in public statements but are generally motivated to enhance their cash positions Graaskamp (1989). Space users are typically consumers who purchase real estate either for their occupation or commercial use. Future users are future consumers who will continue to fuel the demand for real estate. All these Space Consumer Groups require space for shelter, business, market storage, or production purposes. Space Consumer Groups aim to maximise satisfaction. On the other hand, Space Production Group refers to property developers, who are the producers in the system, seek to maximise profits (Graaskamp, 1989). Property developers include every individual or party who is involved in converting raw land into real estate products such as agricultural, industrial, commercial or residential properties. Property developers typically identify sites, acquire them, design, finance, build and all process in relation to developing properties (Harvey, 1987). Space production group or real estate developers require materials, skills and capital to develop real estate. Materials include construction resources, machinery and technology required to build real estate. Skills refer to skilled professionals in the building industry such as architects, engineers, and professional contractors. Another crucial component being Capital refers to the method of financing the development, either through equity or debt funds Graaskamp (1989). The public infrastructure group refers to infrastructure investors for the provision of roads, transportation systems, security systems, educational systems, utilities, sewerage and other facilities in relation to infrastructure that complements the properties. Their ultimate aim is to maximise social benefits. However, there is a certain infrastructure that is profit-driven as well but still provides some benefits socially or economies of scale. The interactions between these three players require financing to see through their goals. Thus, this gives the rise to a real estate finance system.

\subsection{Real Estate Finance System}

Within the real estate system, the development and investment in real estate require huge capital upfront which is an expensive investment that creates a huge barrier of entry (Harvey, 1987). Thus, the 
e-issn: $2229-8568$

need for a financial market to finance these expensive investments and developments made the formation of a real estate finance system possible, where financial institutions are instrumental in the channelling of funds (Abel, 2005). The investment in real estate depends on the ability to raise funds through the financing mechanism that is available to enable tangible development and investment in real property to take place. The real estate finance system filled the gap of connecting finance to the development and investment of real estate (Cummings, 2006). As a result, the real estate sector had opened up opportunities to a variety of jobs and employment, such as professionals, manufacturers, real estate developers, contractors, suppliers, builders and financial institutions alike.

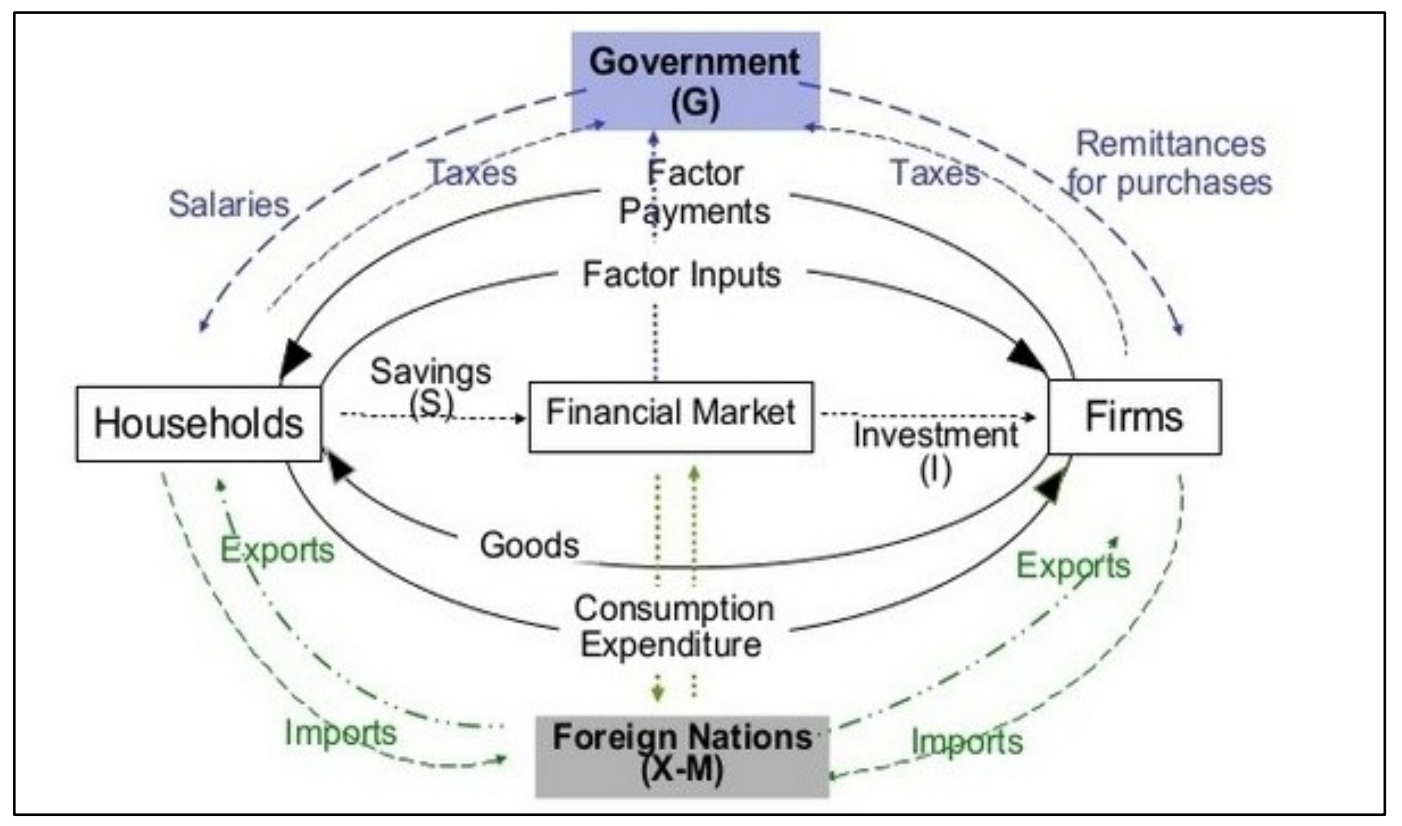

Figure 2: Circular Flow of Income in Four Sector Economy

Source: Murphy, 2008

Murphy (2008) described the circular flow of income among key players in the economy consisting of the government, households, firms and foreign nations. The financial system lies in the core of the circular flow, acting as intermediaries and as a financier in both bridging and end financing in the real estate market. Consumers or households, usually homeowners or businesses will invest in real estate, rent, or lease properties for consumption (Murphy, 2008). Firms, on the other hand, consist of property developers who will seek to acquire land and develop real estate to be sold to households or consumers. They will receive bridging finance from the real estate finance system to fund their development (Glickman, 2014). Households or consumers, on the other hand, will receive end financing from financial institutions to fund their lease or purchases. The government will then regulate the market through a variety of fiscal and monetary policies, especially tax and interest rates (Glickman, 2014; Abel, 2005; Harvey, 1987). Financial instruments are instrumental in the mobilisation of money and credit to develop and acquire real estate (Glickman, 2014; Harvey, 1987). The form of financing provided by financial institutions to property developers and purchasers alike in the form of bridging financing and end financing respectively creates a finance system where loans known as the real estate finance system (Clauretie \& Sirmans, 2003). Real estate finance systems are complex, characterised by heterogeneity, according to how the fund is organised and the main sources of capital (Lunde \& Whitehead, 2016). The housing finance systems are normally grouped into four categories, namely Bank Oriented System, Mortgage Bond System, Mortgage Backed Securities System and State System (Lunde \& Whitehead, 2016). 
e-issn: $2229-8568$

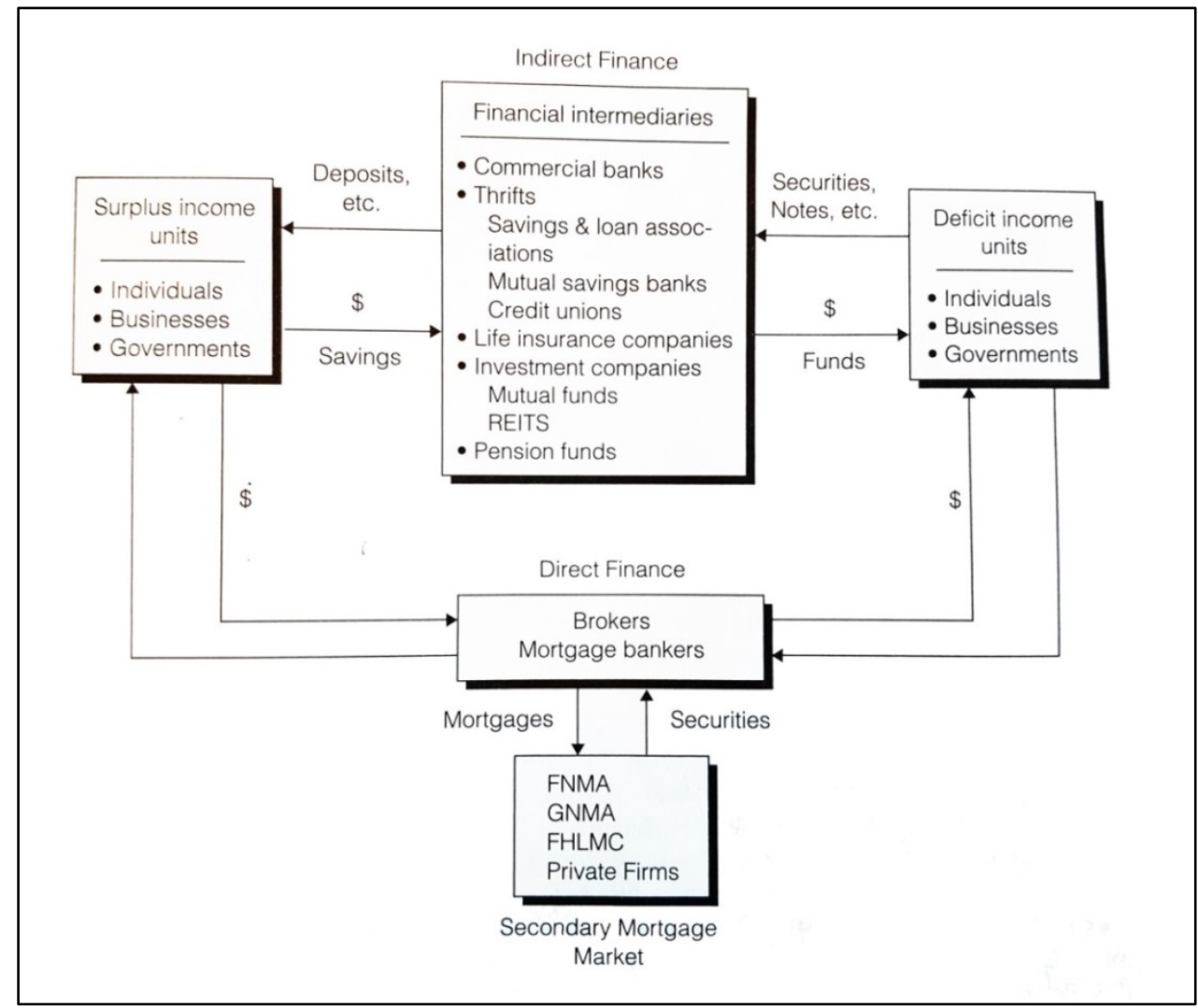

Figure 3: Flow of Funds in the Savings-Investment Cycle Source: Clauretie, 2003

The above figure shows the dynamic flow of funds in the savings-investment cycle. This is part of the real estate finance system. The surplus income units were shown on the left side of the figure with funds to lend. On the other hand, the deficit income units, which need to borrow credit. Surplus and deficit income units were broken down into three categories namely, individuals (households), businesses and government. Commercial banks accept deposits in savings and may also borrow funds from other sources (Glickman, 2014; Abel, 2005). Together, these funds are advanced to individuals, firms and governments. The huge amount of finance required to fund real estate development and investment, illiquid nature of properties, high risks and fixated location of an asset made it difficult for the financial institution to finance real estate and provide financing that caters to both firms (property developers) and consumers demand (Glickman, 2014; Abel, 2005). Thus, two submarkets of the real estate finance system were developed by most countries, known as the primary and secondary mortgage markets (Claurentine, 2003; Watanabe, 1998).

The primary mortgage market is the market where borrowers and mortgage originators come together to negotiate terms and effectuate mortgage transactions (Claurentine, 2003; Watanabe, 1998). An example of this situation is where a commercial bank or mortgage company makes a loan to a property purchaser, and then this transaction becomes part of the activity of the primary mortgage market. Mortgage brokers, mortgage bankers, credit unions and banks are all part of the primary mortgage market. After being originated in the primary mortgage market, most mortgages are sold into the secondary mortgage market. Such mortgages usually end up as part of a package of mortgages that comprise mortgage-backed securities (MBS), asset-backed security (ABS) or collateralised debt obligation (CDO). The primary mortgage market is made up of primary lenders. The activity of various financial institutions and real estate loan providers in primary mortgage markets can be seen in various countries. They are usually controlled by a regulator in their respective country. For instance, in the United States, financial institutions are regulated by the Federal Reserve System (Meltzer, 2010). Their deposits are insured by the Federal Deposit Insurance Corporation (FDIC). They are an important source of commercial real estate loans in the primary mortgage market, especially loans for the acquisition, 
e-issn: $2229-8568$

development and construction of properties. Aside from commercial banks and financial institutions, there are also lending institutions that specialised in real estate loans. Such example is the Korean Real Finance System where property loans are initially provided by the Korea Housing Bank and the National Housing Fund (both are government institutions). Commercial banks made entry into the Korean housing finance system in 1996 with instalment finance companies in 1997 (Bank of Korea, 2013). Korean Housing Bank was privatized in 1999, paving the way for the development of the secondary market as there was intense competition among the mortgage provider (Bank of Korea, 2013). In Japan, the Japan Housing Finance Agency (JHF) focuses on the securitization support business to support the provision of fixed-rate housing loans by private financial institutions, but also provides a housing loan insurance service to promote the smooth provision of private housing loans and a loan origination service in areas that are important from the policy perspective, yet difficult for the private sector to handle (Sakakibara, 2004). Japanese Government's Housing and Loan Corporation was the largest mortgage institution in 1996, before the Asian financial crisis of 1997 (Sakakibara, 2004). In Canada, the Canadian Mortgage and Housing Corporation (CHMC) was established in 1946 to assist war veterans in finding housing (Treasury Board of Canada, 2007). The corporation then expanded its mandate to assist all Canadians in the provision of loans and affordable housing. The CMHC was also authorized to guarantee timely payment in the pool of insured federal loans. These financial institutions and lenders all played a role in the primary mortgage market.

Primary lenders typically keep the loans they originate as part of their portfolio and service them for the life of the loan in the primary mortgage market (Glickman, 2014). Claurentine (2003) identified some advantages of the primary mortgage market to property loan borrowers which include (i) low closing costs: Primary lenders are typically locally-owned, community banks. That means that the lenders can do all of the paperwork and documentation in-house instead of going through a corporate chain, thus eliminating most of the fees that come along with closing a loan on the secondary mortgage market. (ii) Flexibility: Because the originators of the loan are typically locally-owned banks, it is more likely that the borrowers will be able to communicate with the people who get the final say, which is unlikely to happen at a national bank. This provides more flexibility if the borrowers have a unique financial situation. (iii) Lower Upfront Payments: The upfront payment or known as "margin of financing" is usually lower to enable developers and consumers to have more cash flow or the affordability required, to finance their real estate developments and properties respectively (Clauretie \& Sirmans, 2003). However, there are various problems associated with the primary mortgage lenders and a secondary mortgage market is established to address these problems. In the past, before the secondary mortgage market was established, only larger banks had extensive funds to provide the funds for the life of the loan, usually for 15 to 30 years (Lea, 1999). In times of financial crisis, the supply of funds can be greatly affected by macroeconomic conditions (Clugston, 2009) as few funds are being available to create mortgages or fund projects. As a consequence, the limited amount of mortgages in the market had resulted in extremely high costs of lending due to a rise in interest rates (Clauretie \& Sirmans, 2003). This eventually leads to potential homebuyers had a more difficult time finding mortgage lenders. In addressing the issue of the high costs of financing and risks involved in financing such loans and mortgages, the real estate finance system evolves and a secondary mortgage market is developed through the creation of special purpose vehicles (SPVs) to complement the primary mortgage market (Clauretie \& Sirmans, 2003). The creation of the secondary mortgage market and SPVs allows the selling of mortgage loans and raise funds for financial institutions even before the maturity date of the loan (Said, 2015; Glickman, 2014; Abel, 2005). 


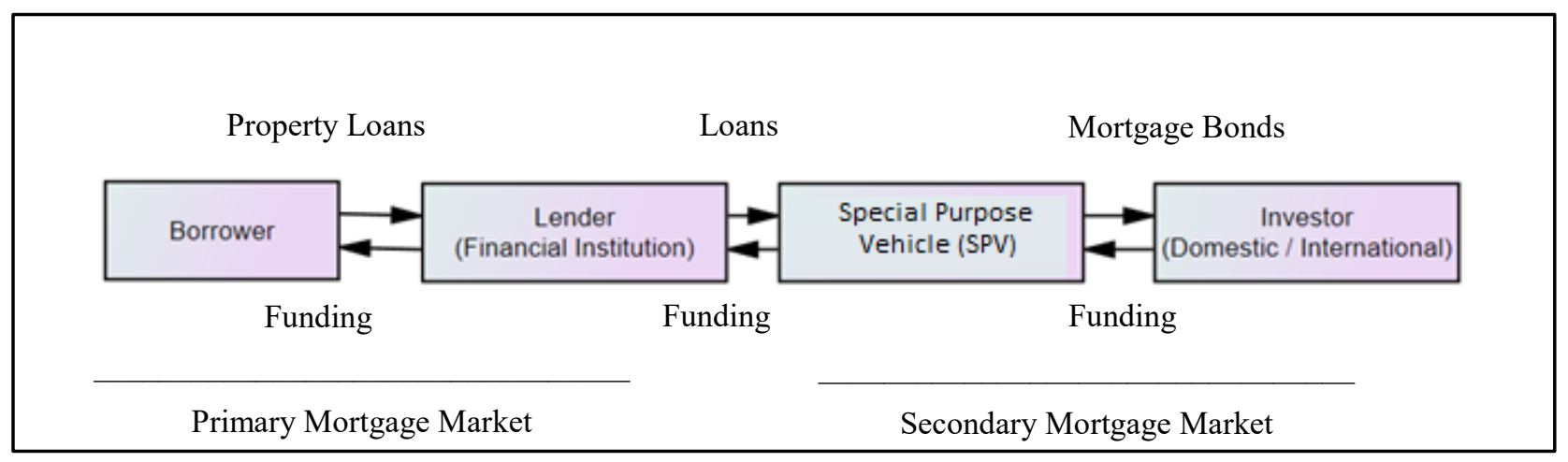

Figure 4: Typical Primary and Secondary Mortgage Market, extended from Rosli Said (2015) Source: Author; Said, 2015

As shown in the figure above, the SPVs are instrumental in the securitisation of mortgages into MBS. The Secondary Mortgage Market is where home loans and servicing rights are bought and sold between lenders through SPVs and investors (Clauretie \& Sirmans, 2003). The secondary mortgage market helps to make credit equally available to all borrowers across geographical locations. The loan originators sell a large percentage of newly originated mortgages at the secondary mortgage market, where they are packaged into MBS and sold to investors via SPVs. Investors include pension funds, insurance companies and hedge funds (Clauretie \& Sirmans, 2003).

Some examples of various SPVs in secondary mortgage markets can be seen as follows:-

Table 1: Special Purpose Vehicle in Selected Countries

\begin{tabular}{|l|l|}
\hline Country & Special Purpose Vehicle in the Secondary Mortgage Market \\
\hline United States & Freddie Mac \& Fannie Mae \\
\hline Mongolia & Mongolian Mortgage Corporation (MMC) \\
\hline Korea & Korea Housing Finance Corporation (KHFC) \\
\hline Thailand & Secondary Mortgage Corporation of Thailand (SMC) \\
\hline Indonesia & PT Sarana Multigriya Finansial (SMF) \\
\hline Philippines & National Home Mortgage Finance Corporation (NHMFC) \\
\hline
\end{tabular}

Secondary mortgage markets are helpful and necessary to the success of primary mortgage markets as they make securities more liquid (Said, Adair, McGreal, \& Roh, 2015). A buyer of security in the primary mortgage market will be concerned if it is difficult to resell the security. Investors do not like securities that are not easily sold. The reduction in the marketability risk due to a large and efficient secondary mortgage market leads to a reduction in the yield required by investors in the primary mortgage market. However, a reduction in the yield required by investors in the primary mortgage market translates to lower borrowing costs for borrowers (Glickman, 2014). In this way, the secondary mortgage market lowers the costs of completing the savings-investments flow of funds, enhancing liquidity and reducing risks within the real estate finance system (Said, Majid, \& Alastair, Relationship and lead-lag effect between the housing market and housing finance system in Malaysia: An ARDL Approach, 2013). The development of secondary mortgage markets can be seen in various countries throughout the world. In the United States, Fannie Mae and Freddie Mac were created as SPV in the secondary mortgage market (Frame, Tracy, \& Vickery, 2015). These government-sponsored businesses were able to buy bank mortgages and resell them to other investors. Instead of reselling the loans individually, they were bundled into MBS, which means their value is secured or backed by the value of the bundle of mortgages. Freddie Mae and Freddie Mac are both similar but differ slightly where Freddie Mae mostly buys mortgages from commercial banks while Freddie Mac buys from smaller 
e-issn: 2229-8568

banks (Frame, Tracy, \& Vickery, 2015). There are also agencies such as the Federal National Mortgage Association, Government National Mortgage Association, Home Loan Mortgage Corporation that are involved in the US secondary mortgage market. They issue MBS through brokers to fund the purchase of mortgages. The cash flow stream from the mortgages is used to service the interest payments on the mortgage-related securities. In Korea, the Korean secondary mortgage market came into existence with the establishment of Korean Mortgage Corporation, a private corporation in 1999 (Bank of Korea, 2013). Korean Housing Finance Corporation (KHFC) was a product of the merger of Korean Mortgage Corporation and the nation's Housing Loan Guarantee Fund and it was re-organised as a public corporation. KHFC purchases mortgage loans originated by commercial banks and package them into MBS (Bank of Korea, 2013). Australia also shares an interesting history in its development of the secondary mortgage market. The Australians initially issues promissory notes by the National Mortgage Market Corporation for mortgage loans, followed by the establishment of the First Australian National Mortgage Acceptance Corporation by the government of the New South Wales State in 1986, the first state institution to issue long term securities in Australia (Hayre, 2001). The two earlier institutions are partly owned by the public and partly private sector owned. In Canada, the SPV of the Government National Mortgage Association (Ginnie Mae) was created based on the American model of Cannie Mae is established, an MBS (Treasury Board of Canada, 2007). For over 50 years, Ginnie Mae has provided liquidity and stability, serving as the principal financing arm for government mortgage loans and ensuring mortgage lenders have the necessary funds to circulate in the economy. Due to the development of a modern real estate finance system, the primary and secondary mortgage markets had enabled real estate loans to be provided and channelled efficiently within the market.

\subsection{Background of Malaysia}

Malaysia is a fast-growing developing country with great potential. Malaysia has a total land area of 329,847 square kilometres. Malaysian population based on the 2020 census is 32.73 million people (Statistics Department of Malaysia, 2020). The Malaysian Gross Domestic Product (GDP) had grown at $4.8 \%$ between 2000 and 2018 (IMF, 2019). In 2018, the Malaysian economic growth was at $3.6 \%$, one of the lowest since the 2009 financial crisis. Weaker net exports of goods and services, as well as slower public consumption, resulted in sluggish growth. Malaysia also possesses the third largest economy in Southeast Asia (IMF, 2019). Throughout the past three decades, Malaysia had faced and sheltered through several financial crises.

\subsection{Malaysia during the 1996-1997 Financial Crisis}

The Malaysian Real Estate Finance system experienced the highest NPL ratio in 1998, which was 20.4\% (IMF, 2019). The bad economic situation during 1997 was the main reason for high NPLs for that year (Ariff \& Abubakar, 1999). Prior to the financial crisis of 1997-1998, the Malaysian economy had been growing strongly during the 1990 s with an average growth rate of $8.5 \%$ (Said, et al., 2015). The Malaysian economy was even dubbed as one of the miracle economies in Southeast Asia, with high growth rates averaging 7.4\% between 1970 to 1996 (World Bank, 2020). However, in 1997 Malaysia's GDP growth recorded negative growth of $7.3594 \%$ a contrast, compared to its previous 37 years of positive growth. At that period of time, the Malaysian banking system began to experience increasing non-performing loans (NPLs), which rose from 2.18\% in June 1997 to 4.08\% in December 1997. Ultimately at the peak of the crisis, the Malaysian NPL stood at $11.45 \%$ in July 1998 (Bank Negara Malaysia, 1997-2018). Only then, the crisis brought upon the realization to policymakers that the threat of the crisis was real, and that unless a clear stand was taken, the crisis would only gradually deepen (Ariff \& Abubakar, 1999). Approximately five months later, the Finance Minister introduced a response package consisting of tight monetary and fiscal policies including the postponement of infrastructure projects (such as the Bakun Dam, Express Rail Link, and the land bridge to Thailand), maintaining competitiveness and policies to strengthen the country's balance of payments account. In 1997 however, the sign of crisis appeared as market confidence in the South East Asian region declined. The effects of the crisis were a depreciation of ringgit and an increase in non-performing loans. Financial institutions and finance companies were severely affected and there are a lot of corporate failures while 
e-issn: $2229-8568$

equity markets plunged. The policy response to these financial problems was to tighten fiscal and monetary policy to curb the crisis. Unlike the rest of the Asian countries affected by the Financial Crisis, Malaysia did not implement an IMF program but used several policy changes to control the effects of the Financial Crisis. Malaysia pegged the ringgit to the dollar and imposed selected capital controls to stabilize the currency (ringgit) and stop the capital outflow which was beyond the capability of the government to control. According to Nambiar (2009), among the policy responses to the 1997-1998 crisis are the increment of interbank rate from 7.6\% in September 1997 to 8.7\% in December 1997. The three-month interbank rate was then further increased to $11 \%$ in February 1998. However, the interest rate was found to have no effect in controlling the value of the ringgit. Some of the early monetary policies implemented include the limiting of loans to the property sector and for shares financing (Nambiar, 2009). The requirements of disclosure of NPLs were also reduced from six months arrears to three months for early detection of the NPL problems.

Aside from monetary and fiscal policies being implemented, the Malaysian government also plays a pivotal role in the recovery process of severe non-performing loans in the real estate finance system. During the 1997-98 financial crisis, the Malaysian government introduced the National Economic Recovery Plan, which is formulated with the ultimate goal of rescuing Malaysia from the financial crisis. The measures taken under the plan were improving and boosting macroeconomic fundamentals, maintaining market stability, strengthening the ringgit, continuing the equity and socioeconomic agenda and restoring adversely affected sectors. The Malaysian government also spent a total of RM12 billion to rescue several troubled banks. Subsequently, the Malaysian government has taken respective actions to solve the financial problems through the development of two SPVs known as the Danaharta Nasional Berhad and Danamodal Berhad in 1998. Danaharta restructures Malaysian financial institutions whose equity had fallen below nine percent. Financial restructuring involves attempts to restore solvency, raise additional capital, reduce liabilities, and boosting the value of assets. Danaharta also helps to buy non-performing loans from financial institutions and remove non-performing loans from the sheets of financial institutions and reduce the financial institutions' debt burden which prevented them from carrying out their functions. Danamodal Berhad on the other hand facilitates and eases the burden of NPL by recapitalizing banking institutions and had invested RM6.4 billion in ten institutions from 1998 to 1999. Danamodal Berhad injected a lot of new capital in selected institutions. Another effort by the Malaysian government is Operational Restructuring which is implemented by the Central Bank of Malaysia via the Corporate Debt Restructuring Committee aimed to improve the Bank's strategies, management and accounting systems, better credit assessments and collateral valuations. The effectiveness of Danamodal Berhad and Danaharta Berhad was palpable. After their inception, nonperforming loans declined to $15.3 \%$ of total loans by the end of 2000 , and bank balance sheets are improved tremendously (Bank Negara Malaysia, 2002). The Central Bank of Malaysia also issues the important "Guidelines on Classification of Impaired Loans/ Financing Provisions \& Provisioning for Bad and Doubtful Debts" which highlights the classification of impaired loans, treatment of interest income on impaired loans, reclassification of impaired loans as an unimpaired loan, provisioning of loans and responsibilities of key banking management personnel. These taxation policies and guidelines issued to financial institutions are financial regulations, monetary and fiscal policies that help to manage both macroeconomic determinants and the quality of banking assets of non-performing loans in reducing credit risks.

Unfortunately, despite these measures, the threats of rising NPLs still exist. A lack of study into the macroeconomic factors affecting NPLs had been proven to cause delays in managing and controlling the levels of NPPLs (IMF, 2016).

The economic downturn of 1997 affected a lot of Asian countries including Malaysia, prompting huge and frequent concerns about the concepts of non-performing loans. During the downturn, Malaysia's GDP shrank from US\$100.8 billion in 1996 to US\$72.2 billion in 1998, while the non-performing loans rose 7\% end of March 1997 to 8.9\% by the end of June 1998 (Bank Negara Malaysia, 1997-2018). The Malaysian economy's GDP did not recover to 1996 levels until 2003. However, there had been little discussion to focus on non-performing property loans, which was considered as a sub-set of the larger picture of non-performing loans. Nonetheless, the non-performing 
property loans became more important as it constitutes a large percentage of the overall non-performing loans, and this affects the profitability of the financial institutions in Malaysia directly.

\subsection{Malaysia During the 2007-2008 Global Financial Crisis}

The financial crisis of 2007-2008 was caused by excessive risk-taking by banks in the United States, unmonitored loan repayment defaults (NPLs) which eventually saw the downturn of the real estate finance system in the US, specifically the subprime mortgage market (Demyanyk \& Hemert, 2009). The downfall of the subprime mortgage market eventually led to the downfall of several major financial institutions including the 160 year old Lehman Brothers, a global financial institution. While there had been many studies and debates on the cause of the global financial crisis, many economists concurred that the subprime lending, growth of the housing bubble and increase of NPLs had been instrumental in triggering the global financial crisis (Grauwe, 2008; Demyanyk \& Hemert, 2009; Williams, 2010). The rise of mortgage origination, excessive lending, poor regulations in the financial industry and unfavourable systemic economic conditions were the main causes of the subprime mortgage crash in the US (Williams, 2010). The spill over effects from the US subprime mortgage crisis affected the global economy as the US accounts for more than $33 \%$ of the growth in global consumption between 2000 and 2007 (Kim, Kim, \& Lee, 2015). Kim, et al (2015) found that the spill over effects of the US subprime mortgage crisis were significantly contributed by the collapse of Lehman Brothers and the downfall of the US economy. Being the largest economy in the world at that time, the downfall of the US economy had impacted international economies. In early 2009 , various countries start to see declines in annualized GDP growth, including the European Union (fell by $9.8 \%$ ), Germany $(15.2 \%$ ), Japan (7.4\%), UK (7.4\%), and Latvia (18\%) (IMF, 2019).

The deterioration in global economic conditions and spill-over effects of the Subprime Mortgage Crisis in the US can be seen in Malaysia. After the 1996-1997 Asian Financial Crisis, the Malaysian economy grew at an average annualized rate of 5.5\% from 1999 to 2008 (World Bank, 2020). However, in 2009, following the subprime mortgage crisis, Malaysia faces a decline of only $1.5 \%$ in that year. The collapse of Lehman Brothers alone, with a US\$600 billion bankruptcy filing had directly impacted financial losses in banks and insurers that used Lehman as their prime broker and fund manager throughout the world. Despite being a trading partner of the US, Malaysia had been able to handle and absorb the systemic risks well. The concerted and pre-emptive measures taken by the Bank Negara Malaysia (BNM), through the accelerated implementation of fiscal stimulus, supported by the easing of monetary policy and the introduction of comprehensive measures to sustain access to financing and mitigate any impact of the heightened risk aversion among banks contributed towards stabilizing the domestic economy in the second quarter and its subsequent recovery in the second half of the year (Ibrahim, 2014). The economy resumed its growth momentum in the fourth quarter, growing by $4.4 \%$. Continued expansion in domestic demand and increased external demand led to the strong growth of $7.42 \%$ in 2010 . Then, the Malaysian economy grew at an average rate of $5.4 \%$ per annum from 2010 to 2018 (World Bank, 2020).

The importance of monetary policy strategy had been a crucial factor in the implementation of sound monetary and fiscal policies in the sheltering and prevention of economic crises. 
e-issn: $2229-8568$

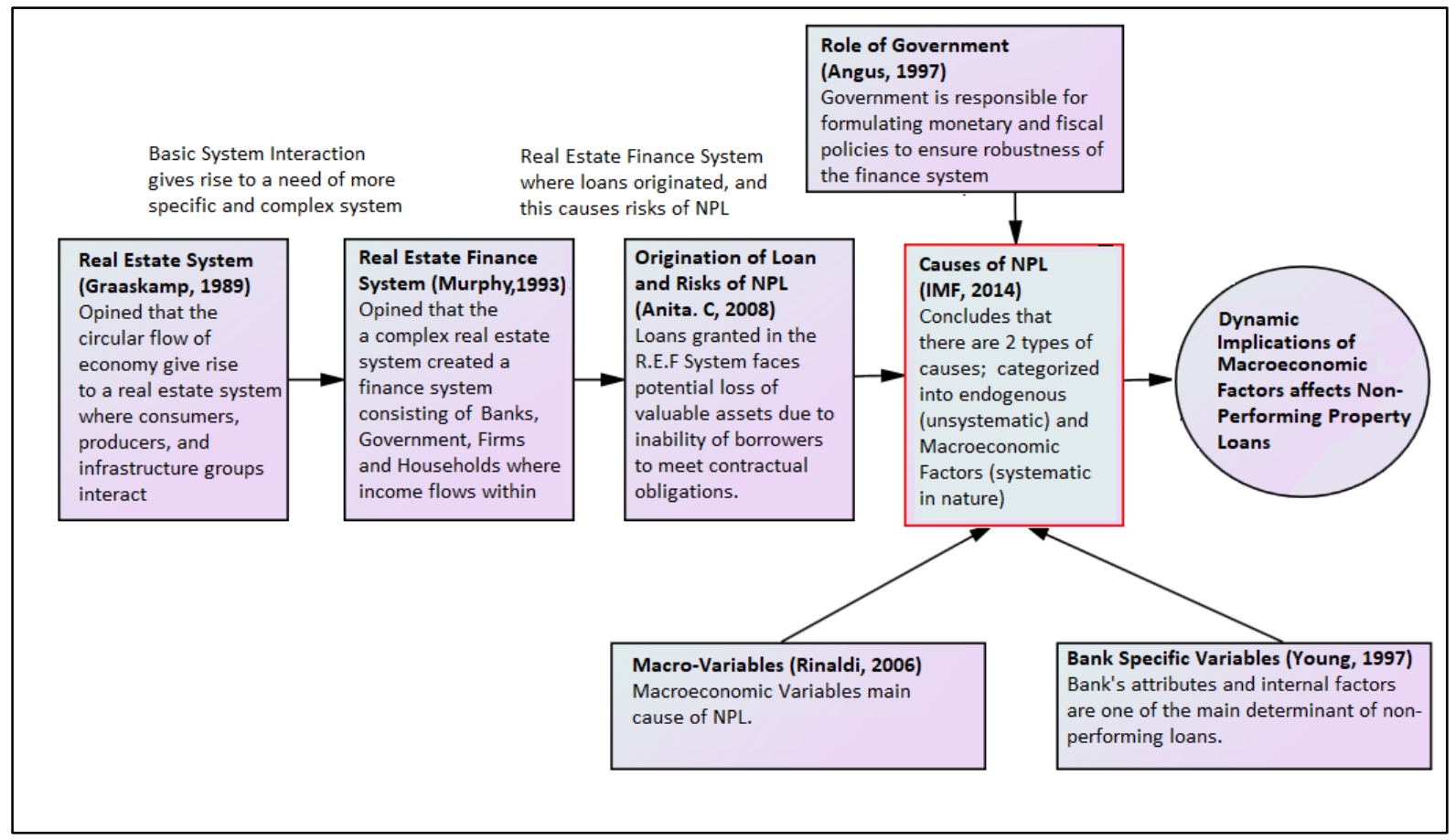

Figure 5: Deductive Reasoning on the Evolution of Real Estate Finance System and the Origination of the Non-Performing Property Loan

Source: Author, based on Theories from Various Journals and Publications

\subsection{Non-performing Property Loans}

Property is a unique asset class where it is heterogeneous in nature (Harvey, 1987). Property Loans are the largest composition of loans (30-40\% of the total NPLs) in value for financial institutions in many countries including the US and Malaysia (Federal Reserve of USA, 2013-2018; Bank Negara Malaysia, 1997-2018), afflicting the largest risk to their respective country's economy. In the USA alone, residential and non-residential real estate loans constitute about $45 \%$ of the total bad loans, followed by Commercial \& Industrial Loans, Consumer Loans and others. Even in terms of portfolio, property loans lent out remain as the major constituent of assets and source of income by financial institutions. Hence, its impact on the financial system would be most significant. Moreover, property loans contain a longer repayment period compared to other loans like credit card, vehicles and the purchase of fixed movable assets. Hence, the impact on the real estate finance system would potentially be longer as well (Bank Negara Malaysia, 2018). This calls for the research into short and long-term dynamic relationships between macroeconomic factors and NPPLs. The underlying asset of the NPPLs are of immovable property, a heterogeneous asset that is distinct from one another in location and physical attributes, and harder to recover due to the exorbitant price, especially in a downturn economy which renders it an even higher risk of default and collapse (Valencia, 2018; Demyanyk et al., 2009).

As more property loan defaults increase in the entire financial industry, a systemic phenomenon of credit illiquidity caused by macroeconomic factors will cause a group or all financial institutions within a country to collapse, leading to a systemic banking crisis (Valencia, 2018). A systemic real estate financial crisis is a situation where a country's corporate and financial sectors experience a rising number of NPLs, with corporations and financial institutions face great difficulties repaying their debt obligations on time (Campbell, 2007; Beck, 2006). The real estate financial system then collapses, where no loans in property can be lent out, and servicing of property loans eventually fell abruptly throughout the country (Hou, 2007). This can be seen during the sub-prime mortgage crisis in the USA, where the rising loan defaults in property loans eventually bring the real estate finance system to its knees (Williams, 2010). 
e-issn: $2229-8568$

\subsection{METHODOLOGY}

In order to understand the functioning of the Malaysian real estate finance system and to identify the origination of the non-performing property loan, the approach of this research is a descriptive research approach, and the analysis technique being adopted is case studies and desk studies.

\subsection{Case Studies and Desk Studies}

Desk studies and deductive reasoning is used in this study due to the availability of research materials from journals and publications. Desk studies are involved in collecting data from existing resources and this is useful in gathering data to establish the foundations of the theories supporting the origination of the non-performing loan, existing real estate finance systems in other countries and Malaysia, and the interactions within the financial system. On the other hand, deductive reasoning is the process of reasoning from one or more statements (premises) to reach a logically certain conclusion (Sternberg, 2009) For the identification of the loan origination process in Malaysia, deductive reasoning is on a top-down approach is utilized. Deductive reasoning is adopted with the top-down logic where the circular flow of the economy gives rise to a real estate finance system, which in turn explains the origination of the non-performing loan. Both techniques are suitable for the literature study as many of the theories required to establish the origination of non-performing loans had existed. The sources of data here are mainly analysing and synthesising the theoretical foundations published in books and journal articles. For the identification of the real estate finance system in Malaysia and the observation of the property NPLs, desk studies are conducted mainly in analysing and synthesising facts and figures from secondary data sources which include journal articles, books and annual reports from official sources such as the World Bank, International Monetary Fund and the Central Bank of Malaysia.

The Case Study begins with a systemic review of Malaysia's existing real estate finance system structure, followed by the loan originators in Malaysia. Then, the loan originators were analysed with relation to the primary mortgage system, followed by the securitization process under Malaysia's exclusive special purpose vehicle, CAGAMAS. Lastly, the non-performing property loans are examined in detail and synthesized in terms of their composition and historical performance to arrive at describing the current condition of non-performing property loans in Malaysia.

\subsection{RESULTS AND DISCUSSION}

\subsection{The Malaysian Real Estate Finance System}

In Malaysia, the Real Estate Finance System in Malaysia involves three sub-markets namely the primary mortgage market, the secondary mortgage market and the capital market (Said, Adair, McGreal, \& Roh, 2015). The three submarkets are dependent and interact with each other in delivering the successful operation of the real estate finance system. As shown in Figure 6 below, there are several stakeholders; mainly the government, property purchasers \& developers, financial institutions, and capital market investors. The following findings will discuss the role of Malaysian financial institutions, loan processing, mortgage markets, capital market and the government's role in regulation and recovery of non-performing loans. 
e-issn: $2229-8568$

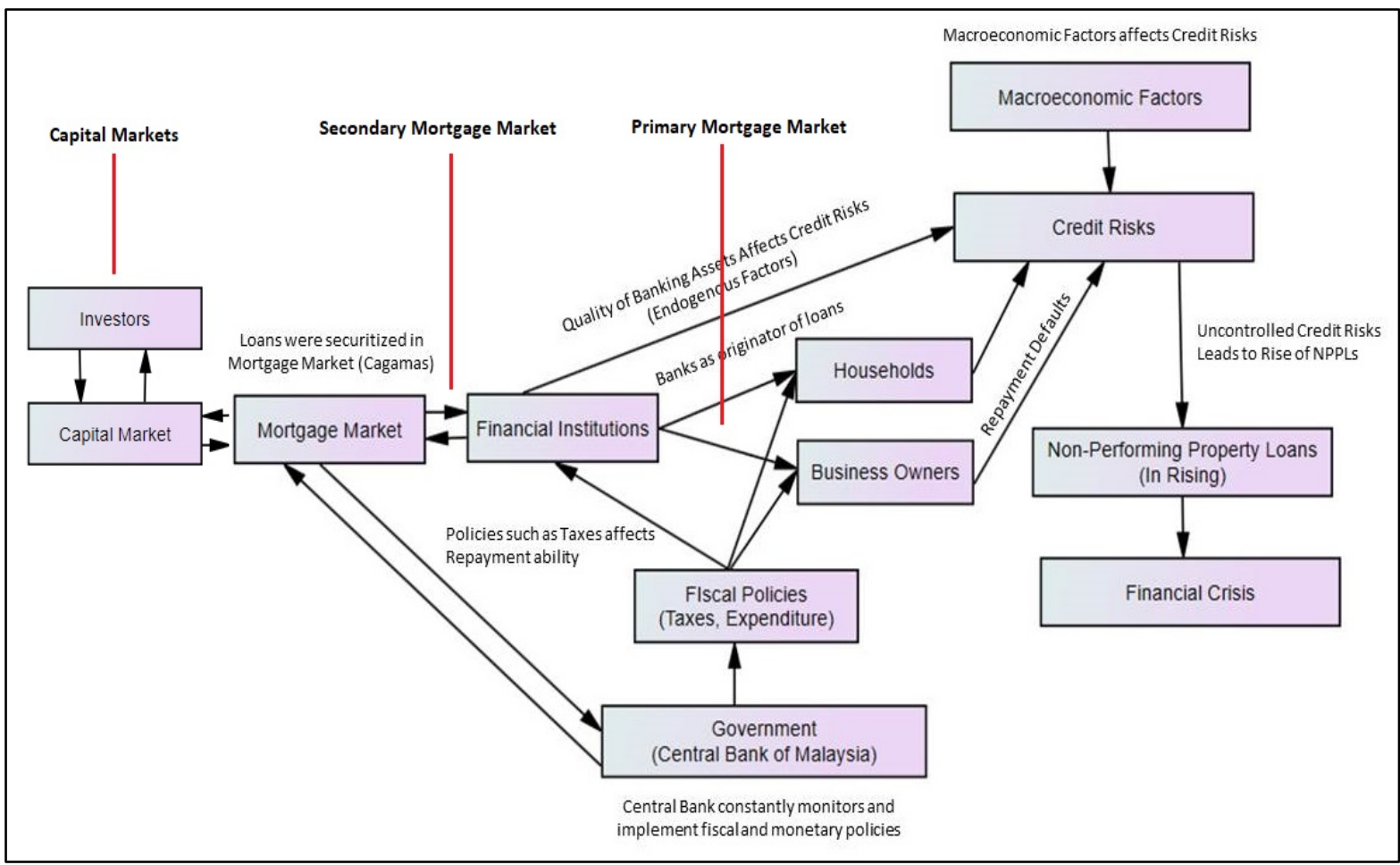

Figure 6: Interactions between the Real Estate Financing System and Risks of Non-performing loans in Malaysia, extended from Rosli Said (2015)

Source: Author; Said, 2015

\subsection{Property Loan Originators in Malaysia}

In Malaysia, loan originators consist of Commercial Banks, Islamic Banks, International Islamic Banks, Investment Banks and Special Institutions ( Bank Negara Malaysia, 2018). In total, there are a total of 57 financial institutions in Malaysia. There are currently 26 Commercial Banks, 16 Islamic Banks, 2 International Islamic Banks, 11 Investment Banks and 2 Special Financial Institutions ( Bank Negara Malaysia, 2018). There are also non-financial institutions that provide loans mainly to their staff. Property loans originated from financial institutions are financed or refinanced by entities (Cagamas) within the financial system, but not necessarily the case for property loans originated by other financial institutions. While the financial institutions are the largest and main originators of the property loans for both developers and purchasers, the Treasury Housing Loan Division is a big originator of the housing loans for the public sector. However, the loans by the Treasury Loans Department determine their interest rate at a fixed rate of $4 \%$ per annum due to government subsidy, which is different from the licensed financial institutions in Malaysia which had to subscribe to the Base Lending Rate, which fluctuates and set by the Central Bank of Malaysia. At some points, the financial institutions also provide property loans to the public sector.

The overview of licensed financial institutions for commercial banks in Malaysia can be seen as follows:

Table 2: List of Licensed Commercial Banks in Malaysia

\begin{tabular}{|l|l|}
\hline 1) Affin Bank Bhd & \begin{tabular}{l} 
14) India International Bank \\
\hline 2) Alliance Bank Bhd
\end{tabular} \\
$\begin{array}{l}\text { 15) Industrial and Commercial Bank of China } \\
\text { Bhd }\end{array}$ \\
\hline 3) Ambank Bhd & 16) JP Morgan Chase Bhd \\
\hline 4) BNP Paribas Bhd & 17) MUFG Bank Malaysia Bhd \\
\hline 5) Bangkok Bank & 18) Malayan Banking Bhd \\
\hline 6) Bank of America & 19) Mizuho Bank \\
\hline 7) Bank of China & 20) OCBC Bank Bhd \\
\hline
\end{tabular}




\begin{tabular}{|l|l|}
\hline 8) CIMB Bank & 21) Public Bank Bhd \\
\hline 9) Citibank Bhd & 22) RHB Bank Bhd \\
\hline 10) China Construction Bank & 23) Standard Chartered Bank Bhd \\
\hline 11) Deutsche Bank & 24) Sumitomo Mitsui Banking Corporation \\
\hline 12) HSBC Malaysia Bhd & 25) The Bank of Nova Scotia Bhd \\
\hline 13) Hong Leong Bank Bhd & 26) United Overseas Bank Bhd \\
\hline
\end{tabular}

Source: Central Bank of Malaysia, 2018

There are also 16 Islamic Banks as follows: -

Table 3: List of Licensed Islamic Banks in Malaysia

\begin{tabular}{|l|l|}
\hline 1) Affin Islamic Bank Bhd & 9) Hong Leong Islamic Bank Bhd \\
\hline 2) Al Rajhi Banking \& & 10) Kuwait Finance House (Malaysia) Bhd \\
\hline Investment Corporation (Malaysia) Bhd & 11) MBSB Bank Bhd \\
\hline 3) Alliance Islamic Bank Bhd & 12) Maybank Islamic Bhd \\
\hline 4) AmBank Islamic Bhd & 13) OCBC Al-Amin Bank Bhd \\
\hline 5) Bank Islam Malaysia Bhd & 14) Public Islamic Bank Bhd \\
\hline 6) Bank Muamalat Malaysia Bhd & 15) RHB Islamic Bank Bhd \\
\hline 7) CIMB Islamic Bank Bhd & 16) Standard Chartered Saadiq Bhd \\
\hline 8) HSBC Amanah Malaysia Bhd & \\
\hline
\end{tabular}

Source: Central Bank of Malaysia, 2018

Commercial banks are major players in the real estate financing system. They are the largest and most important suppliers of funds in the banking system. Commercial banks were initially placed under the supervision of the Bank Negara Malaysia (BNM) in 1959. Prior to the inception of BNM, commercial banks had only to comply with the Companies Ordinance 1948. The Banking Act 1973 was subsequently replaced in 1989, banking and financial Institutions Act 1989 (BAFIA), which combines the Banking Act 1973 and Finance Companies Act 1969 in a single law. The main function of commercial banks is to provide retail banking services, such as accepting deposits, granting loans and advances, and financial guarantees. Apart from that, commercial banks provide trade financing facilities such as trust receipts, Banker's Acceptance, shipping guarantees and letters of credit. Commercial banks are also authorized. Risks are usually defined as the negative impact on the profitability of many various sources of uncertainty. Investment banks in Malaysia are responsible as a financial intermediary that performs a variety of services, primarily in raising capital and security underwriting, mergers and acquisitions, and sales and trading for both institutions and private investors. Islamic Banks serve similar purposes with Commercial banks, but with the inclusion of adherence to Syariah principles in banking. Banks and financial institutions, being the source of loan origination plays a pivotal role in the system and functions in the primary mortgage. They are involved in lending to both the business sector and households for the purchase of properties (Said, Adair, McGreal, \& Roh, 2015). There are also special institutions that are formed that provide property loans to consumers.

These special institutions can be seen as below: -

Table 4: Special Institutions that are Property Loan Originators in Malaysia

\begin{tabular}{|l|l|l|}
\hline Special Institution & $\begin{array}{l}\text { Establishment } \\
\text { Date }\end{array}$ & Notes \\
\hline $\begin{array}{l}\text { Treasury Housing } \\
\text { Loan Division }\end{array}$ & 1970 & $\begin{array}{l}\text { The Housing Loan Division is established by the Ministry of } \\
\text { Finance Malaysia aimed to assist the financing of public } \\
\text { housing in Malaysia. }\end{array}$ \\
\hline $\begin{array}{l}\text { Bank Kerjasama } \\
\text { Rakyat }\end{array}$ & $\begin{array}{l}\text { Bank Kerjasama Rakyat is an Islamic cooperative bank that is } \\
\text { an entity under the control of the Ministry of Domestic Trade, } \\
\text { Cooperatives and Consumerism. }\end{array}$ \\
\hline
\end{tabular}


e-issn: $2229-8568$

\begin{tabular}{|l|l|l|}
\hline $\begin{array}{l}\text { Malaysia Building } \\
\text { Society Berhad }\end{array}$ & 1950 & $\begin{array}{l}\text { The Malaysian Building Society Berhad is a government- } \\
\text { linked company where its largest stakeholders being the } \\
\text { Employee Provident Fund and Permodalan Nasional Berhad. } \\
\text { It is instrumental in being one of the major sources of property } \\
\text { loans in Malaysia. }\end{array}$ \\
\hline $\begin{array}{l}\text { Borneo Housing } \\
\text { Mortgage Berhad, }\end{array}$ & 1958 & $\begin{array}{l}\text { Borneo Housing Mortgage Berhad is the principal agent } \\
\text { appointed by the State Government of Sabah and Sarawak to } \\
\text { provide and manage housing financing for the civil servants } \\
\text { in the two States including employees of Government } \\
\text { agencies and statutory bodies. }\end{array}$ \\
\hline $\begin{array}{l}\text { Bank Simpanan } \\
\text { Nasional Berhad }\end{array}$ & 1974 & $\begin{array}{l}\text { Bank Simpanan Nasional is a government-owned bank based } \\
\text { in Malaysia. }\end{array}$ \\
\hline $\begin{array}{l}\text { Sabah Credit } \\
\text { Cooperation }\end{array}$ & $\begin{array}{l}\text { The primary objective of the Corporation is to help contribute } \\
\text { towards the socio-economic development of the State of } \\
\text { Sabah. In its capacity as a financial institution, the } \\
\text { Corporation complements the Sabah State Government's } \\
\text { efforts by providing or facilitating financial credits to promote } \\
\text { and encourage private investment involving agriculture, light } \\
\text { industry, development of rural and urban housing, shophouses } \\
\text { and public utilities and amenities. }\end{array}$ \\
\hline
\end{tabular}

Source: Compiled by Author based on Bank Negara Malaysia, 2019

In analysing the main originators of property loans in Malaysia, financial institutions were the main providers of property loans in 2019 , with a market share of approximately $85 \%$, followed by special institutions including the Treasury Housing Loans division at 15\% (Bank Negara Malaysia, 1997-2018). These financial and special institutions, being the originators of loans hold major nonperforming loans risks from the borrowers. These risks, in the form of non-performing loans, cause losses for banks when loan repayments are in default by households or business owners who are the borrowers. The largest composition of non-performing loans in Malaysia is related to property. In the past decade of the year 2007 to 2017, non-performing property loans account for an average of $33 \%$ of the total non-performing loans in Malaysia, the highest composition over the values of other types of non-performing loans subgroups such as the purchase of car, fixed assets other than land and building, credit cards, consumer durable goods, working capital and other purposes. Thus, due to the nature of business of financial institutions in lending, non-performing loans' risk remains their largest challenge and a high degree of attention is given to credit risks, including improving the quality of banking assets (endogenous factors).

\subsection{Malaysian Primary Mortgage Market}

In the Malaysian Primary Mortgage Market, the originators of real estate loans are the institutions within the financial system as well as non-financial private enterprises (Said, Adair, McGreal, \& Roh, 2015). The primary lenders being the licensed financial institutions in Malaysia originate property loans in the Malaysian Primary Mortgage Market. Unlike the United States of America, the primary lenders (licensed financial institutions) also provide loans in the form of bridging finance to finance property developers to develop and build properties. In this context, pools of property loans are traded in the Malaysian Secondary Mortgage Market but are for the bridging finance whereas property loans originated by the Treasury Division of Malaysia are mostly end-financing for purchasers. In the past, loans extended to the broad property sector such as construction, real estate and housing projects in 1960 represents about 2.9\% of total loans and advances (Said, Adair, McGreal, \& Roh, 2015). As the phase of industrialisation begins in the $1980 \mathrm{~s}$, loans to the same market activities increased to $20 \%$. However, the loans to the same sector accounted for only $18.2 \%$ and $17.5 \%$ of the total loans and advances for 2004 and 2005 respectively. In recent years from 2005 to 2019, the purchase of properties constitutes the largest type of total loans in Malaysia, accounting for $30-40 \%$ of the total loans in Malaysia (Bank Negara Malaysia, 1997-2018). Many different parties participate in the primary mortgage market. Borrowers obviously are in the market looking for money, but several types of loan 
e-issn: $2229-8568$

originators will work with the borrower to create a real estate loan. The primary mortgage market is where borrowers and mortgage originators meet and negotiate to create a mortgage loan. Loans are originated in the primary mortgage; originators can include mortgage brokers, mortgage bankers, commercial banks and credit unions as primary sources. The primary sources are regarded as the conventional sources of finance to real estate (Cummings, 2006). Oftentimes, after the borrower has used their mortgage loan to purchase their home, the bank with whom he or she worked to originate the loan will sell his or her loan. This means that the borrower must now make payments to the different entity that now owns his or her loan. In Malaysia, these financial institutions are the most important creators of mortgages, making funds available for property financing including for residential and nonresidential property loans. These bulk of financial institutions usually span more than $80 \%$ loan to value ratio and can go as high as $95 \%$ for first-time homebuyers, spanning to a maximum term of 35 years as of 2018 (Bank Negara Malaysia, 1997-2018). Once a loan has been established, it could be sold to another financial institution, by this entering the secondary mortgage market. Many companies in the financial industry are involved in both the primary and secondary mortgage markets. On the primary mortgage market, lenders such as banks and credit unions can connect with people who want to borrow money. They help borrowers with information about the available options. Mortgage brokers work with borrowers to package them, by collecting information about their income, assets, etc. Then they present potential lenders with a complete package of information that can be used to establish a loan. Households borrow property loans usually for the purpose of purchase of residential houses while business owners purchase properties or their business usage, or for investments. Default of repaying their loans on time results in the occurrence of non-performing property loans for either group. Evidence shows that the financial institutions over-lent on the upcycle, resulting in non-performing property loans each time the property market collapses. As a result, unmanaged non-performing property loans created instability in the real estate finance system.

\subsection{Malaysian Secondary Mortgage Market}

Due to the need for a guarantee for the loans being originated in the primary mortgage market to ensure there is continuity in the real estate finance system, the secondary mortgage market comes into play. The supply of funds for real estate development and investment can be greatly affected by economic conditions. In times of financial crisis, little or no fund is available to create mortgages or fund projects and the few mortgages may attract high interest rates. Due to the nature of mortgage loans are very specific and indivisible, it is extremely illiquid as it is a long term commitment, especially in terms of emergency and urgent need to recoup cash, and it becomes difficult for the loan to be liquidated within a short time. Hence, this calls for a market to sell loans and raise funds even before the maturity date of the loan (Watanabe, 1998). The secondary mortgage market presents itself to meet this need. In Malaysia, the secondary mortgage market was incepted with the creation of the National Mortgage Corporation (CAGAMAS) in 1987. CAGAMAS is neither classified as a financial institution nor listed on the Kuala Lumpur Stock Exchange (KLSE). As its status is a non-financial institution, CAGAMAS is exempted from the strict supervision and regulation imposed by the government on other financial intermediaries. Under the Malaysian Secondary Mortgage Market, the originators of the property loans have the opportunity to sell their housing loans to CAGAMAS to increase their liquidity as well as a hedge against interest rate risks. Malaysia took pride in CAGAMAS as it is one of the foremost and established secondary mortgage markets in the Asian continent. Malaysian secondary mortgage market manages to create a stable primary mortgage market, with good regulatory guidelines and procedures for property financing through the capital market (Cagamas Berhad, 2018). CAGAMAS is established based on a public-private partnership model and has three functions (Leong, 2014). The first is to reduce the maturity mismatch in the banking system. The second is to assist asset securitisation and deepen the capital market. The third is to help extend the mortgage maturity and introduce new mortgage innovations so that house-buyers can afford to buy with a longer maturity (higher affordability) and also introduce new products, such as fixed rate mortgages. Secondary mortgage markets have been successfully established in different countries, taking various forms to suit indigenous needs. Interest in secondary mortgage mechanisms is continuing to grow as governments in emerging economies are beginning to recognise the potential for getting private investors to fund the primary mortgage market through the securitization of mortgage assets. While the concept of the Secondary Mortgage Market is 
e-issn: $2229-8568$

based on the USA model as described in the previous chapter, the concept of the Malaysian Mortgage Market is slightly different. As a loan is sold, it is sold on the secondary mortgage market. Mortgage originators sell their loans on the secondary mortgage market to investors or mortgage aggregators. The secondary mortgage market is the market for the sale of securities or bonds collateralised by the value of mortgage loans. In the United States, a mortgage lender, commercial banks, or specialized firm will group many loans from the primary mortgage market and sell grouped loans known as collateralised mortgage obligations (CMOs) or MBS (MBS) to investors such as pension funds, insurance companies and hedge funds. These state sponsored enterprises dominated this scene in the United States. Mortgage-backed securities were often combined into collateralised debt obligations (CDOs), which may include other types of debt obligations such as corporate loans.

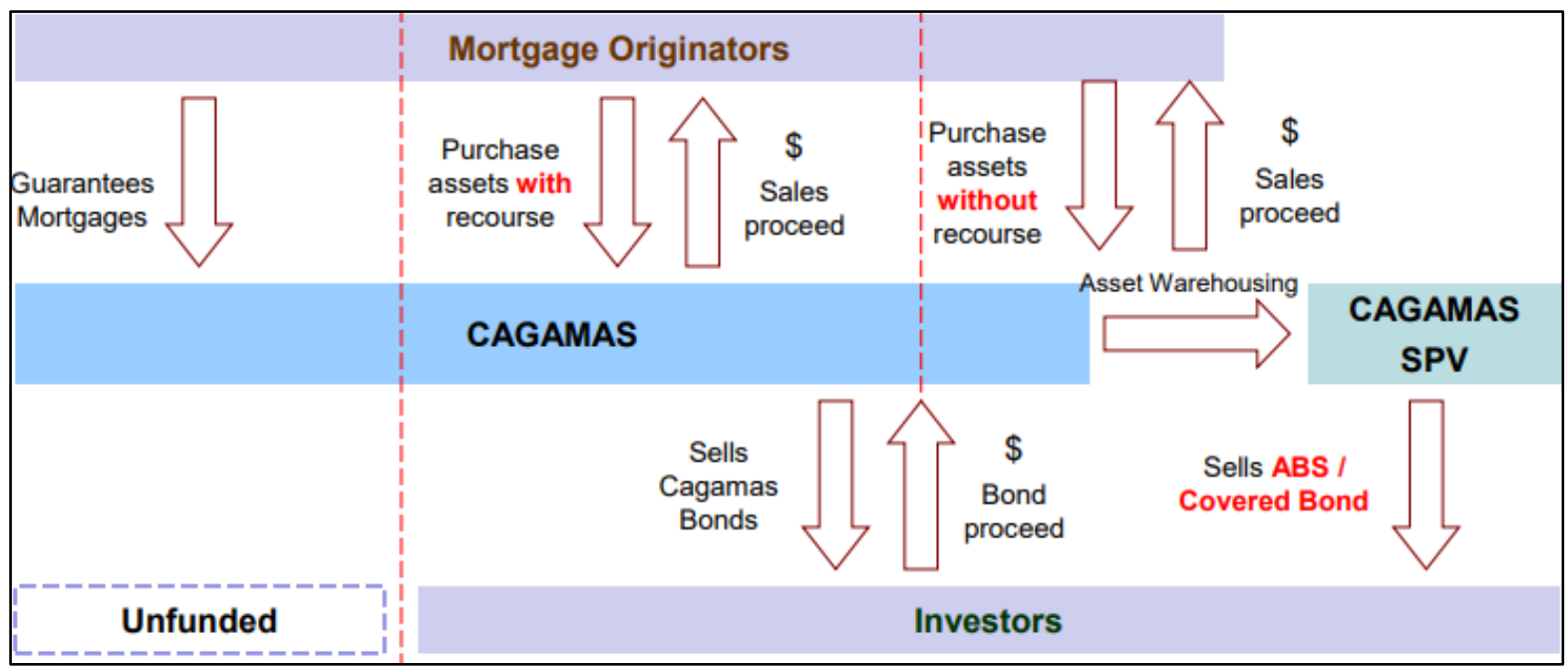

Figure 7: The CAGAMAS Model in the Malaysian Secondary Mortgage Market Source: CAGAMAS, 2013

In theory, the risk of default on individual loans was greatly reduced by this aggregation process, such that even high-risk individual loans could be treated as part of an AAA-risk (safest possible) investment. However, unlike the secondary mortgage market in the United States that is mostly dominated by state sponsored enterprises, CAGAMAS is the only entity that operates the secondary mortgage market in Malaysia. In the Malaysian Secondary Mortgage Market, pools of property loans are sold to Cagamas which in turn, issue private debt securities by securitising loans in the Malaysian Capital Market to finance the primary mortgage market. Therefore, CAGAMAS played a crucial role to serve as the SPV between the originators of property loans in the Malaysian primary mortgage market with the investors in the Capital Markets. As seen in Figure 4.5 above, in acting as the intermediary of selling the pool of real estate loans to the Malaysian secondary mortgage market, the financial institutions can acquire more funds to grant more property loans. With more funds created in the Malaysian primary mortgage market, the financial institutions and investors of the capital markets face the risks of non-performing loans due to default of payments by borrowers. Yet, the role of CAGAMAS provides an alternative source of financing to the private sector apart from the conventional bank borrowings. CAGAMAS had been implemented successfully in Malaysia. CAGAMAS played a critical, catalytic and decisive role in the growth of private debt securities in Malaysia (Lea, 1999).

\subsection{Malaysian Capital Markets and Role within the Malaysian Real Estate Finance System}

The Malaysian capital market is governed by the Securities Commission of Malaysia (SC) and Bursa Malaysia (formerly known as the Kuala Lumpur Stock Exchange). Both played a pivotal role in improving dealings, increasing transparency, disclosure, accounting, and improving corporate governance that was among the pillars of a sound and stable exchange market. The performance of Bursa Malaysia can be assessed by analysing the Kuala Lumpur Composite Index (KLCI). According to Figure 4.6 below, the Malaysian capital markets had been growing steadily from 1999 to 2007, before 
the global financial crisis where it tumbled from 2008 to 2009, and then recovered from 2009 to 2013, and then subsequently fluctuates from 2015 to 2019. The Malaysian capital market had been growing similarly to Singapore for the last two decades. The growth rates increased in 1999 after the 1998 Asian Financial Crisis but dropped again in 2001 and 2003. The growth then continued until 2007 where it then plunged due to the 2007 Global Financial Crisis. However, the Malaysian capital market recovers the following year in 2008, with a steep rise, before fluctuating between 2013 and 2018.

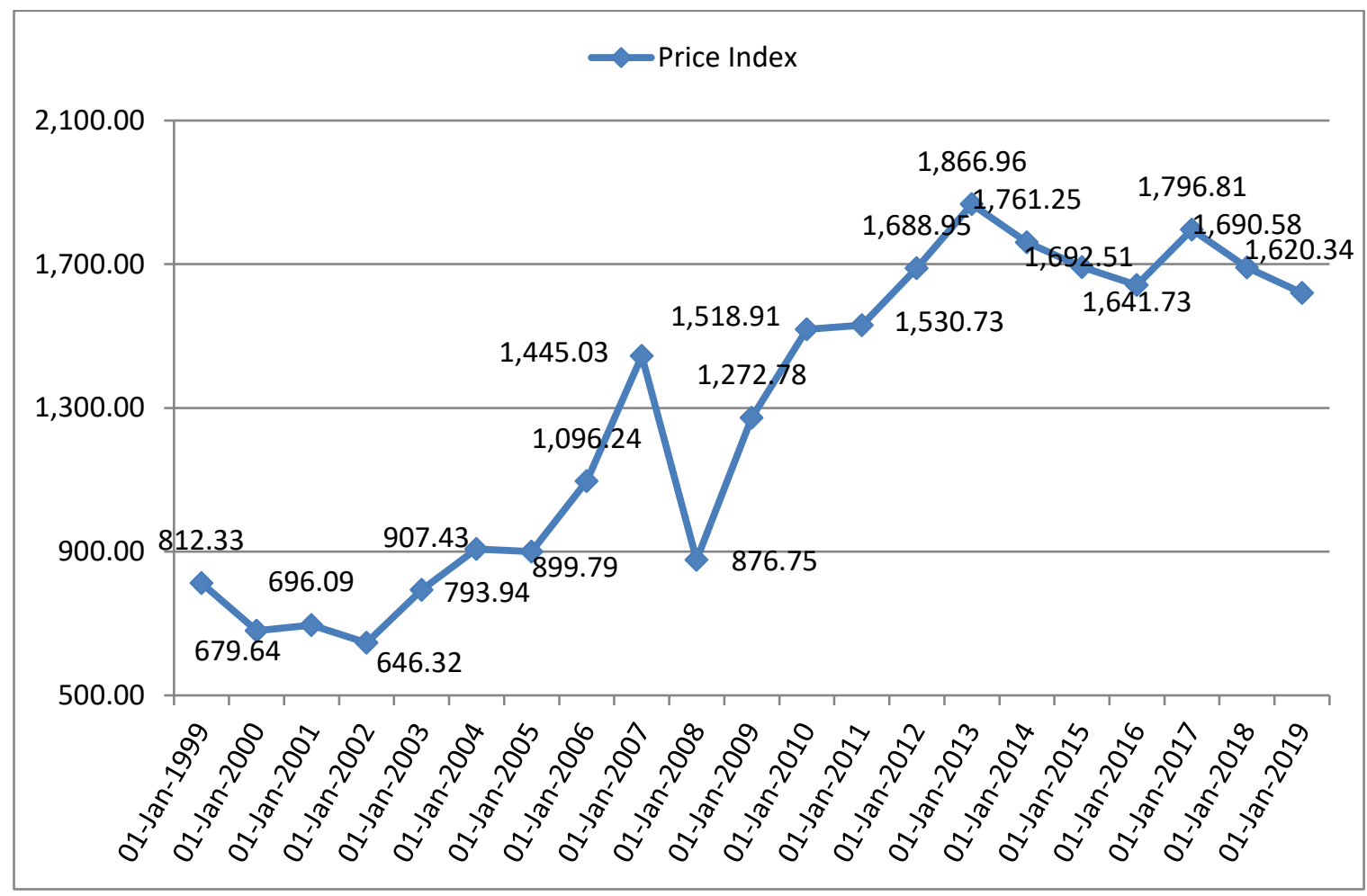

Figure 8: Performance of the KLCI Price Index from 1999 to 2018. Adopted from Eikon, Thompson Reuters (2019)

Source: Thompson Reuters, 2019

Malaysia's strong corporate earnings, corporate mergers, and the various Malaysian development plans were found to be major contributory factors to the performance of the capital market over the last two decades. Malaysia's capital market offers a source of long term financing for the real estate industry (Leong, 2014). The Malaysian primary mortgage market creates large and rapidly growing pools of property funds that are then sold to CAGAMAS to be securitised in the Malaysian Capital Market by the issuance of private debt securities (PDS). These securities are then traded off in the bond market to institutional investors and in return, help to induce the performance of the Malaysian capital market. Many of these institutional investors consist of financial institutions, insurance companies, pension funds, non-resident companies, and international firms who are interested in the Malaysian Capital market to obtain a fixed or adjustable rate income. One of the largest institutional investors is the Malaysian Employee Provident Fund (EPF). As of March 31, 2018, the size of the EPF asset size stood at RM814 billion. (US\$200 billion), making it the fifth largest pension fund in Asia and seventh largest in the world (EPF, 2019). The performance of CAGAMAS can be traced since the issuance of its PDS known as CAGAMAS bonds in 1987 with a total value of RM100 million. Since then, as one of the largest issuers of corporate bonds and sukuk in Malaysia, Cagamas has continued to diversify its funding sources and investor base to include a wider range of foreign institutional investors. In 2016, the company issued a total of twenty one new Cagamas bonds and sukuk totalling RM7.4 billion, comprising RM4.9 billion bonds and RM2.5 billion sukuk (CAGAMAS, 2016). The issuances included thirteen new issuances and three reopening of Cagamas bonds and sukuk in ringgit as well as five new Cagamas FCY issuances. RM6.0 billion or $81 \%$ was raised from the ringgit bond market while the remaining RM1.4 billion or 19\% was issued under the Company's Multicurrency (EMTN) 
e-issn: $2229-8568$

Programmes. In the Malaysian Capital Market, factors contributing to the movement of yields are inflation outlook and interest rates (Murthy, 2016). The vibrant and active bond market requires sound macroeconomic policies to promote the country's growth prospect. Thus, uncertainties within macroeconomic conditions and the introduction of new policies had always been a concern that may not only affect the capital markets but the primary and secondary mortgage markets as well.

\subsection{Non-Performing Property Loans in Malaysia}

The Malaysian Central Bank provides non-performing loans data in two categories, 3 months default periods and 6 months default periods (Bank Negara Malaysia, 1997-2014). Non-performing loans are then further breakdown into their purposes which consist of twelve categories. There is the purchase of securities, purchase of vehicles, purchase of passenger cars, purchase of residential property, purchase of non-residential property, purchase of fixed assets other than property, personal uses, credit cards, purchase of consumer durable goods, construction, working capital and other uses (Bank Negara Malaysia, 1997-2018).

As shown in Figure 9 below, the number of non-performing property loans in Malaysia had faced a steady decline before 2014. However, from 2015 onwards see a rise in NPPLs.

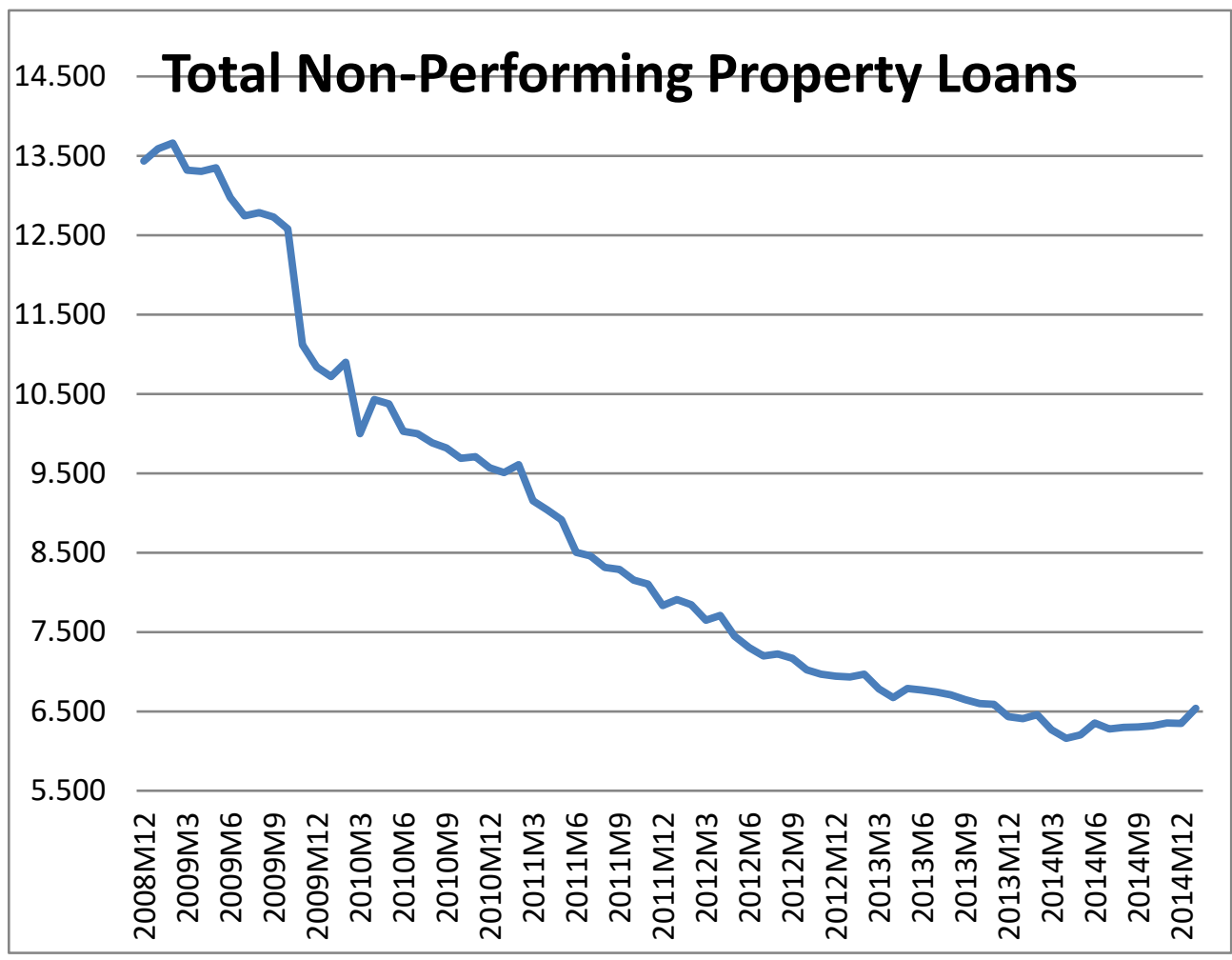

Figure 9: Non-Performing Property Loans in Malaysia Source: Bank Negara Malaysia, 2018

Table 5: Changes in Percentages YoY Basis of Non-Performing Loans and Non-Performing Property Loans Respectively

\begin{tabular}{|c|c|c|c|c|c|}
\hline Year & $\begin{array}{c}\text { Total Non- } \\
\text { Performing } \\
\text { Property Loans } \\
\text { (RM Millions) }\end{array}$ & $\begin{array}{c}\text { Total Non- } \\
\text { Performing Loans } \\
\text { (RM Millions) }\end{array}$ & $\begin{array}{c}\text { Composition of } \\
\text { Non- } \\
\text { Performing } \\
\text { Property Loans }\end{array}$ & $\begin{array}{c}\text { Changes in Non- } \\
\text { Performing } \\
\text { Property Loans (\%) } \\
\text { YoY }\end{array}$ & $\begin{array}{c}\text { Changes in Non- } \\
\text { Performing Loans } \\
(\%) \\
\text { YoY }\end{array}$ \\
\hline 2007 & $68,314.88$ & 176,733 & $38.65 \%$ & Nil & Nil \\
\hline 2008 & $55,506.20$ & 144,573 & $38.39 \%$ & -18.74947 & -18.19694 \\
\hline
\end{tabular}


e-issn: $2229-8568$

\begin{tabular}{|c|c|c|c|c|c|}
\hline Hh,2009 & $49,833.25$ & 126,281 & $39.46 \%$ & -10.22038 & -12.65243 \\
\hline 2010 & $39,385.82$ & 117,286 & $33.58 \%$ & -20.96477 & -7.123003 \\
\hline 2011 & $33,769.17$ & 109,204 & $30.92 \%$ & -14.26058 & -6.890848 \\
\hline 2012 & $29,052.51$ & 94,537 & $30.73 \%$ & -13.96735 & -13.43082 \\
\hline 2013 & $26,612.00$ & 90,295 & $29.47 \%$ & -8.400341 & -4.487132 \\
\hline 2014 & $25,173.96$ & 89,370 & $28.17 \%$ & -5.403727 & -1.024419 \\
\hline 2015 & $26,849.10$ & 89,595 & $29.97 \%$ & +6.654257 & +0.251762 \\
\hline 2016 & $28,734.68$ & 94,580 & $30.38 \%$ & +7.022879 & +5.563926 \\
\hline 2017 & $31,608.60$ & 99,397 & $31.80 \%$ & +10.00157 & +5.093042 \\
\hline
\end{tabular}

Source: Compiled and calculated by the author based on sources extracted from Central Bank of Malaysia 2007-2018

Specifically, if we take a look at Table 5 above, from 2007 to 2013, both Non-Performing loans and Non-Performing Property Loans in Malaysia had been declining healthily. However, a reverse trend can be seen recently, from the year 2014 onwards, rising at an alarming rate of $10 \%$ in 2017 . While the increment of overall non-performing loans in Malaysia at approximately 5\% in years 2016 and 2017, the percentages of increment YoY of Non-performing property loans is more drastically high, recording $7 \%$ in 2016 and $10 \%$ in 2017 respectively.

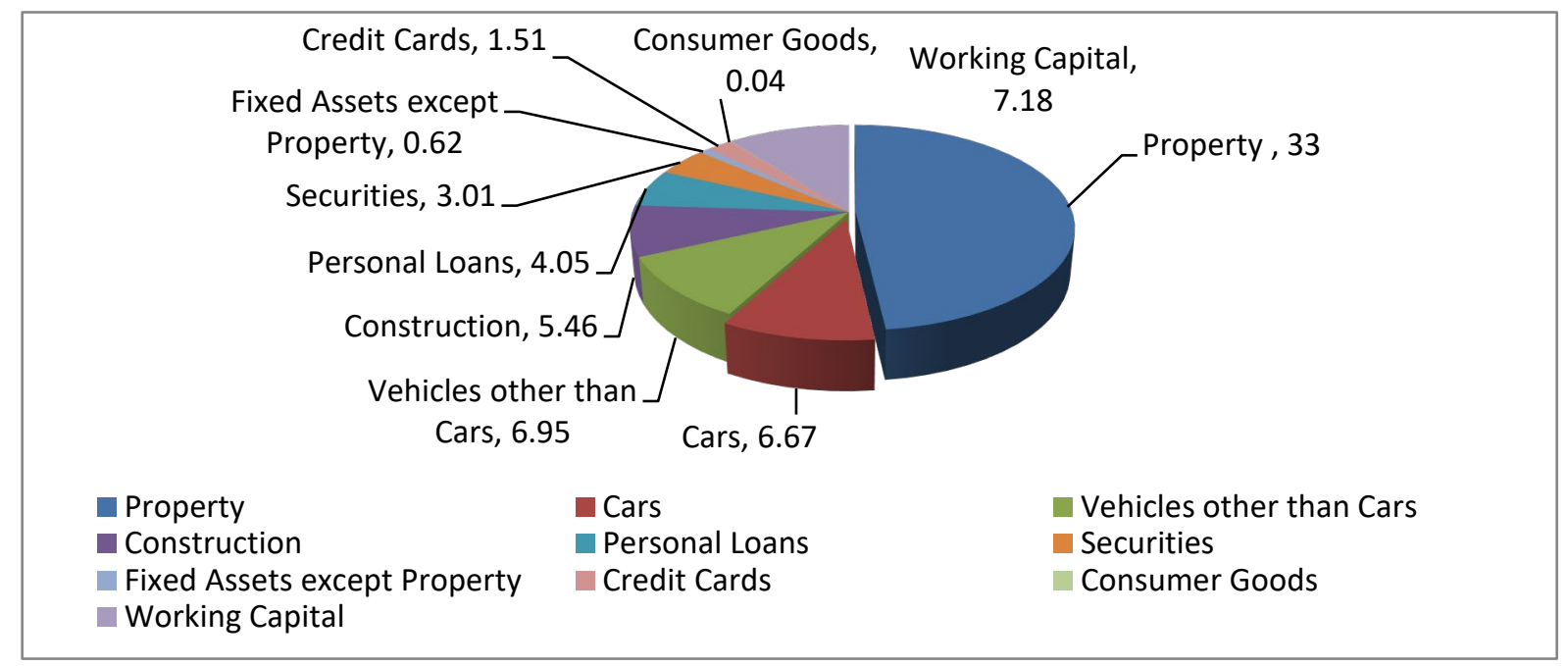

Figure 10: Composition of the Non-Performing Loans in Malaysia by its Purpose (2018)

Source: Compiled by the author based on sources extracted from Central Bank of Malaysia 2018

As shown in Figure 10 above, NPPLs is the largest composition over the other types of nonperforming loans subgroups such as the purchase of car (6.67\%), purchase of transport other than car (6.95\%), construction $(5.46 \%)$, personal loans $(4.05 \%)$, purchase of securities $(3.01 \%)$, fixed assets other than land and building $(0.62 \%)$, credit cards $(1.51 \%)$, consumer durable goods $(0.04 \%)$, working capital and other purposes (7.18\%) (Bank Negara Malaysia, 1997-2018).

Table 6: Composition of Non-Performing Property Loans in overall Non-Performing Loans

\begin{tabular}{|l|l|l|l|}
\hline Year & $\begin{array}{l}\text { Total Non-Performing } \\
\text { Property Loans } \\
\text { (RM Millions) }\end{array}$ & $\begin{array}{l}\text { Total Non-Performing } \\
\text { Loans } \\
\text { (RM Millions) }\end{array}$ & $\begin{array}{l}\text { Composition of Non- } \\
\text { Performing Property } \\
\text { Loans }\end{array}$ \\
\hline 2007 & $68,314.88$ & 176,733 & $38.65 \%$ \\
\hline 2008 & $55,506.20$ & 144,573 & $38.39 \%$ \\
\hline 2009 & $49,833.25$ & 126,281 & $39.46 \%$ \\
\hline 2010 & $39,385.82$ & 117,286 & $33.58 \%$ \\
\hline 2011 & $33,769.17$ & 109,204 & $30.92 \%$ \\
\hline 2012 & $29,052.51$ & 94,537 & $30.73 \%$ \\
\hline
\end{tabular}


e-issn: $2229-8568$

\begin{tabular}{|l|l|l|l|}
\hline 2013 & $26,612.00$ & 90,295 & $29.47 \%$ \\
\hline 2014 & $25,173.96$ & 89,370 & $28.17 \%$ \\
\hline 2015 & $26,849.10$ & 89,595 & $29.97 \%$ \\
\hline 2016 & $28,734.68$ & 94,580 & $30.38 \%$ \\
\hline 2017 & $31,608.60$ & 99,397 & $31.80 \%$ \\
\hline
\end{tabular}

Source: Compiled and calculated by the author based on sources extracted from Central Bank of Malaysia 2007-2018

As shown in Table 6 above, the composition of NPPLs accounts for approximately $30 \%$ to $40 \%$ of the total general NPLs in Malaysia in the past decade, from 2007 to 2017. NPPLs being on the rise in Malaysia are a crucial problem as not only it's the most valuable form of NPLs in Malaysia; it is also harder to recover. As compared to loans such as the purchase of stocks, financial institutions simply force the sale of the equities and buy back the shares at a lower value, which is more liquid. If the property collateral of a loan's quality is poor, the bank would have to spend more on the collection of NPPLs. One of the reasons why the NPPLs are harder to recover is because most foreclosures in Malaysia are normally problematic properties (Woei-Chyuan Wong, 2015). The increase in nonperforming property loans in the banking industry due to adverse situation in economic activities requires a solution that is to be implemented at the regulatory and government level as macroeconomic factors is a form of systemic risk (Allen N. Berger, 1997).

\subsection{CONCLUSION}

Malaysia has a unique structure in terms of property loan origination, consisting of commercial and Islamic Banks and special financial institutions. Malaysia also possesses a developed primary and secondary mortgage market. This paper provides an overview of the origination of non performing property loans and how property NPLs had shown persistent and consistent rising trend after 2014 in a relatively stable economy, before the onset of the COVID-19 pandemic in Malaysia. From the preliminary review, the composition of Non-Performing Property Loans in Malaysia accounts for $28 \%$ to $40 \%$ of the total Non-Performing Loans in Malaysia with an average of 33\% for the past decade since 2007 (Bank Negara Malaysia, 1997-2018). While the increment of overall non-performing loans in Malaysia at approximately 5\% in years 2016 and 2017, the percentages of increment YoY of Nonperforming property loans is more drastically high, recording 7\% in 2016 and 10\% in 2017 respectively. Thus, a further study on the causes of the increase of property NPLs in Malaysia is necessary to prevent systemic banking crisis. Policymakers should also continuously monitor the rising NPLs in Malaysia as part of the country's strategic monetary policy towards a sound and robust real estate finance system in Malaysia.

\subsection{REFERENCE}

1. Abel, A. B. (2005). Macroeconomics. Pearson.

2. Adebola, W. Y. (2011). AN ARDL APPROACH TO THE DETERMINANTS OF NONPERFORMING LOANS IN ISLAMIC BANKING SYSTEM IN MALAYSIA . Arabian Journal of Business and Management Review.

3. Agnello, L. F. (2011). Fiscal Policy Discretion, Private Spending, and Crisis. NIPE Working Papers.

4. Allen N. Berger, R. D. (1997). Problem Loans and Cost Efficiency in Commercial Banks. Journal of Banking and Finance.

5. Ariff, M., \& Abubakar, S. Y. (1999). The Malaysian Financial Crisis. In The Developing 
Economies (pp. 417-38). Institute of Developing Economies.

6. Bank Negara Malaysia. (1997-2014). Monthly Buletin Reports. Kuala Lumpur: Central Bank of Malaysia.

7. Bank Negara Malaysia. (1997-2018). Monthly Bulletin Reports. Kuala Lumpur: Central Bank of Malaysia.

8. Bank Negara Malaysia. (November 2018). List of Licensed Financial Institutions in Malaysia. Retrieved November 2018, from Central Bank of Malaysia: http://www.bnm.gov.my/index.php?ch=fs\&pg=fs_mfs_list\&ac=118\&lang=en

9. Bank Negara Malaysia. (2002). 2002 Annual Report. Retrieved 2019, from Bank Negara Malaysia Official Website:

http://www.bnm.gov.my/index.php?ch=en_publication\&pg=en_ar\&ac=6\&lang=en

10. Bank of Korea. (2013). Financial Markets in Korea. Seoul: The Bank of Korea.

11. Beck, T. A.-K. (2006). Bank Concentration, Competition and Crises: First Results. Journal of Banking \& Finance 30, 1581-1603.

12. CAGAMAS. (2016). Annual Report. Kuala Lumpur: CAGAMAS Berhad.

13. Cagamas Berhad. (2018). About Us. Retrieved from Official Website: $\mathrm{http}: / / \mathrm{www}$. cagamas.com.my/about-us

14. Campbell, A. (2007). Bank Insolvency and the Problem of Non-Performing Loans. Journal of Banking Regulation.

15. Chimobi, O. P. (2010). Inflation and Economic Growth in Nigeria. Journal of Sustainable Development, 3(2), 159-166.

16. Clauretie, T. M., \& Sirmans, G. S. (2003). Flow of Funds in Savings Investment Cycle. In G. S. Terrence M.Clauretie, Real Estate Finance (p. 5). Florida University Press.

17. Clauretie, T., \& Sirmans, S. (2003). Real Estate Finance: Theory and Practice. Florida, United States: Florida University Press.

18. Clugston, C. (2009). The Cause of "The Great Recession". Retrieved from $\mathrm{http} / / / \mathrm{www}$.wakeupamerika.com/PDFs/The-Cause-of-the-Great-Recession.pdf

19. Cummings, R. (2006). REITSL: Avoiding Qualitifaction Woes. Financial Digest.

20. Dash, M. K. (2011). The determinants of non- performing assets in Indian commercial. Middle Eastern Finance and Economics Journal.

21. Demyanyk, Y., \& Hemert, O. V. (2009). Understanding the Subprime Morgage Crisis. The Review of Financial Studies, 848-1880.

22. Dicky, D. (1979). Distribution of the Estimators for Autoregressive Time Series with a Unit Root. Journal of the American Statistical Association. 74 (366), 427-431.

23. Dougherty. (4th Ed, Oxford University Press.). Introduction to Econometrics. Oxford.

24. Engle, R. F., \& Granger, C. W. (1987). Co-Integration and Error Correction: Representation, Estimation, and Testing. Econometrica,55(20), 215-276. https://doi.org/10.2307/1913236 
25. EPF. (2019). About Us: Our Success. Retrieved from EPF Official Website: http://www.kwsp.gov.my/portal/en/about-epf/career/our-success

26. Frame, S. W., Tracy, J., \& Vickery, J. (2015). The Rescue of Fannie Mae and Freddie Mac. Journal of Economic Perspectives, 29(2) Spring 2015: 22-52.

27. Gambera, M. (2000). Simple Forecasts of Bank Loan Quality in the Business Cycle. Retrieved from Emerging Issues: http://www.chicagofed.org/digital_assets/publications/risk_management_papers/sr_2000_3.pdf

28. Glickman, E. A. (2014). Real Estate Finance. Oxford, UK: Elsevier Inc.

29. Graaskamp. (1989). Fundamentals of Real Estate Development. Washington: The Urban Land Institute.

30. Granger, C. (1969). Investigating Causal Relations by Econometric Models and Cross-spectral Methods. Econometrica.

31. Grauwe, P. D. (2008). The Banking Crisis: Causes, Consequences and Remedies. CEPS Policy Briefs.

32. Greenwalt, S. a. (1976). Bank loan-loss provisions and the income-smoothing hypothesis: an empirical analysis. Journal of Financial Services Research.

33. Harris, R. (1995). Using Cointegration Analysis in Econometric Modelling. In P. H. Wheatsheaf.

34. Harvey, J. (1987). Urban Land Economics. London: Macmillan.

35. Hayre, L. (2001). Salomon Smith Barney Guide to Mortgage-Backed and Asset-Backed Securities. New York: John Wiley \& Sons.

36. Hoggarth G., S. S. (2005). Stress tests of UK banks using a VAR approach. Bank of England Working Paper, 282.

37. Hou, Y. (2007). The non-performing loans: some bank-level experiences. . 4th AFE-QASS Conference, INEAG.

38. Ibrahim, M. b. (2014). Impact of Global Crisis on Malaysia's Financial System. Washington, DC: Bank for International Settlements (BIS).

39. IMF. (2016). Non-Performing Loans in the ECCU: Determinants and Macroeconomic Impact. Western Hemisphere. IMF Working Papers.

40. IMF. (2019). World Economic Outlook Database. Washington, DC: International Monetary Fund.

41. Investopedia . (2017). Does inflation favor lenders or borrowers? Retrieved from $\mathrm{http} / / / \mathrm{www}$. investopedia.com/ask/answers/111414/does-inflation-favor-lenders-or-borrowers.asp

42. Julia, A. a. (2010). Study Of Correlation Between Average Interest Rate And Non-Performing Loans In The Romanian Banking System During 2006-February 2010.

43. Kalirai H., a. S. (2002). Macroeconomic stress testing: Preliminary evidence for Austria. Austrian, 3.

44. Karl \& Ray. (1989). Principles of Microeconomics. Prentice Hall. 
e-issn: $2229-8568$

45. Kim, B.-H., Kim, H., \& Lee, B.-S. (2015). Spillover effects of the U.S. financial crisis on financial markets in emerging Asian countries. International Review of Economics \& Finance, 192-210.

46. Khan, M. a. (2011). Threshold Effects in the Relationship between Inflation and Growth. Interntional Monetary Fund.

47. Klein, N. (2013). Non-Performing Loans in CESEE: Determinants and Macroeconomic Performance. IMF Working Paper.

48. Koo, J., \& Kiser, S. L. (2001). Recovery from a financial crisis: the case of South Korea. Economic \& Financial Review.

49. Laura Rinaldi, A. S.-A. (2006). European Central Bank. What Explains Household NonPerforming Loans: An empirical Analysis.

50. Lea, L. C. (1999). Providing Long Term Financing for Housing: The Role of Secondary Markets. United Nations Development Programme.

51. Leong, C. C. (2014). The case of a secondary mortgage corporation in Malaysia: Cagamas Berhad. KUALA LUMPUR: CAGAMAS BERHAD.

52. Lockyer, S. N. (1885). Volume 32 - Typical laws of heredity. Nature.

53. Lunde, J., \& Whitehead, C. (2016). Milestones in European Housing Finance. Chichester, UK: John Wiley \& Sons.

54. Meltzer, A. H. (2010). A History of the Federal Reserve. Chicago: University of Chicago Press.

55. Murphy, A. E. (2008). The Genesis of Macroeconomics, . Oxford Scholarship Online.

56. Murthy, U. \&. (2016). Factors Affecting Kuala Lumpur Composite Index (KLCI) Stock Market Return in Malaysia. International Journal of Business and Management, 122.

57. Nambiar, S. (2009). Malaysia and the Global Crisis: Impact, Response and Rebalancing Strategies. ADBI Working Paper Series, 148.

58. Paper, I. W. (2016). Non-Performing Loans in the ECCU: Determinants and Macroeconomic Impact. Western Hemisphere: International Monetary Fund.

59. Rajaraman, B. a. (1999). NPA variations across Indian Commercial banks. Economic and Political Weekly.

60. Roland Beck, P. a. (February, 2013). Non-Performing Loans: What Matters in Addition to the Economy Cycle. European Central Bank Working Paper Series, p. 5.

61. Rosli Said, R. M. (2013). Relationship and lead-lag effect between housing market and housing finance system in Malaysia: An ARDL Approach. AsRES International Conference.

62. Said, R., Majid, R., \& Alaistair, A. (2013). Relationship and lead-lag effect between housing market and housing finance system in Malaysia: An ARDL Approach. AsRES International Conference.

63. Said, R., Adair, A., McGreal , S., \& Roh. (2015). Inter-relationship between the housing market and Housing Finance System : Evidences from Malaysia. International Journal of Strategic

Property Management. 18(2) 
e-issn: $2229-8568$

64. Sakakibara, E. (2004). The Japanese Financial System in Transition. New York: Routledge.

65. Salas, V. a. (2002). Credit risk in two institutional regimes: Spanish commercial and Saving Banks. Journal of Financial Services Research, 203-204.

66. Sinkey, J. F. (1991). Loan-loss experience and risk-taking behvior at large. Journal of Financial Services Research, 43-59.

67. Statistics Department of Malaysia. (2020). Population \& Demography. Kuala Lumpur: Statistics Department of Maaysia.

68. Sternberg, R. J. (2009). Cognitive Psychology. Belmont, CA: Wadsworth. pp. 578. ISBN 978-0495-50629-4.

69. Treasury Board of Canada. (2007). Crown Corporations and Other Corporate Interests of Canada. Ottawa, Canada: President of the Treasury Board.

70. Valencia, L. L. (2018). Systemic Banking Crises Revisited. IMF Working Paper , 18/206:48.

71. Watanabe, M. (1998). New Directions in Asian Housing Finance: Linking Capital Marketand Housing Finance. International Finance Corporation.

72. William R. Keeton and Charles Morris. (1987). Why do Banks' Losses Differ? Economic Review, Issue May, 3-21.

73. Williams, M. (2010). Uncontrolled Risk - Lessons from the Lehman Brothers. New York: McGraw Hill Education.

74. Woei-Chyuan Wong, M. N.-L. (2015). Estimating Apartment Foreclosure Discount in Kuala Lumpur. Pacific Rim Real Estate Society Conference. Kuala Lumpur.

75. World Bank. (2020). GDP Growth (Annual). Washington, DC: World Bank . 